\title{
High-valent metal-oxo complexes generated in catalytic oxidation reactions using water as an oxygen source
}

\section{Shunichi Fukuzumi, *ab Takahiko Kojima, ${ }^{* c}$ Yong-Min Lee, ${ }^{a}$ and Wonwoo Nam*a}

a Department of Chemistry and Nano Science, Ewha Womans University, Seoul 03760, Korea

${ }^{b}$ Faculty of Science and Engineering, Meijo University, Nagoya, Aichi 468-8502, Japan

${ }^{c}$ Department of Chemistry, Faculty of Pure and Applied Sciences, University of Tsukuba, 1-1-1 Tennoudai, Tsukuba, Ibaraki 305-8571, Japan

E-mail:

fukuzumi@chem.eng.osaka-u.ac.jp,kojima@chem.tsukuba.ac.jp,wwnam@ewha.ac.kr 
Abstract: High-valent metal-oxo complexes are produced by successive electron-transfer oxidation of metal complexes with one-electron oxidants in the presence of water, which is an oxygen source in the generation of the metal-oxo complexes. Then, metal-oxo complexes oxidize substrates to yield oxygenated substrates, accompanied by the regeneration of reduced metal complexes. Thus, the oxidation of substrates using oneelectron oxidants can be catalyzed by metal complexes via formation of high-valent metal-oxo complexes by the electron-transfer oxidation of metal complexes in the presence of water as an oxygen source. When water is used as a substrate, water is oxidized by one-electron oxidants to evolve dioxygen via an O-O bond formation process. The one-electron oxidants used for the formation of high-valent metal-oxo complexes can be replaced by much weaker oxidants, when a photosensitizing metal complex, such as $\left[\mathrm{Ru}(\mathrm{bpy})_{3}\right]^{2+}$ (bpy $=2,2$ '-bipyridine), is employed as a photocatalyst, an oxidized form of the photocatalyst, which is generated via photoinduced electron transfer from the excited state to a weaker oxidant, can oxidize metal complexes in the presence of water to afford the high-valent metal-oxo complexes. Thus, the oxidation of substrates, including water oxidation, by weak oxidants can be catalyzed by metal complexes under photoirradiation of the photocatalyst using water as an oxygen source.

Key Words: high-valent metal-oxo complexes; redox catalysis; electron transfer; photocatalyst; photoinduced electron transfer 


\section{Contents}

1. Introduction

2. Synthesis of metal-oxo and catalytic oxygenation of substrates by CAN

3. Catalytic oxidation of water by CAN

4. Catalytic oxygenation of substrates by $\left[\mathrm{Ru}^{\mathrm{III}}(\mathrm{bpy})_{3}\right]^{3+}$

5. Photocatalytic oxidation of substrates

6. Photocatalytic oxidation of water

7. Concluding remarks

8. Acknowledgements

9. References 


\section{Introduction}

High-valent metal-oxo complexes are known as active intermediates in a variety of metal-catalyzed oxidation reactions, such as hydroxylation of alkanes, sulfoxidation of sulfides, epoxidation of olefins, aromatic oxidation and water oxidation [1-19]. In cytochrome P450 enzymes, generation of iron(IV)-oxo porphyrin $\pi$-radical cation species, $\left(\mathrm{P}^{\bullet+}\right) \mathrm{Fe}^{\mathrm{IV}}(\mathrm{O})($ Compound I), requires two electrons and two protons to activate dioxygen $\left(\mathrm{O}_{2}\right)$, as shown in Eq. (1) [20-25]. Compound $\mathrm{I}$ is also generated by the reaction of $(\mathrm{P}) \mathrm{Fe}^{\mathrm{III}}$ with hydrogen peroxide $\left(\mathrm{H}_{2} \mathrm{O}_{2}\right)$, which is a two-electron reduction product of $\mathrm{O}_{2}$, as shown in horseradish peroxidases (HRP) [Eq. (2)] [26-28]. In biomimetic studies, a variety of high-valent heme and nonheme metal-oxo complexes have been prepared by the reactions of synthetic metal complexes with oxygen atom donors, such as iodosylbenzene (PhIO), peracids and hydroperoxides including $\mathrm{H}_{2} \mathrm{O}_{2}$ [1-19].

$(\mathrm{P}) \mathrm{Fe}^{\mathrm{III}}+\mathrm{O}_{2}+2 \mathrm{e}^{-}+2 \mathrm{H}^{+} \rightarrow\left(\mathrm{P}^{\cdot+}\right) \mathrm{Fe}^{\mathrm{IV}}(\mathrm{O})+\mathrm{H}_{2} \mathrm{O}$

$(\mathrm{P}) \mathrm{Fe}^{\mathrm{III}}+\mathrm{H}_{2} \mathrm{O}_{2} \rightarrow\left(\mathrm{P}^{\bullet+}\right) \mathrm{Fe}^{\mathrm{IV}}(\mathrm{O})+\mathrm{H}_{2} \mathrm{O}$

In addition, it has been proposed that generation of $\mathrm{Mn}^{\mathrm{V}}(\mathrm{O})$ species in water oxidation in Photosystem II requires two-electron oxidation of a $\mathrm{Mn}^{\mathrm{III}}$ complex and removal of two protons from water [Eq. (3)] [29-32]. Moyer and Meyer first reported the generation of a high-valent Ru-oxo complex $\left(\left[\mathrm{Ru}^{\mathrm{IV}}(\mathrm{O})(\mathrm{bpy})_{2}(\mathrm{py})\right]^{2+}\right.$ : bpy $=2,2^{\prime}$ bipyridine and py $=$ pyridine) by the two-electron oxidation of $\left[\mathrm{Ru}^{\mathrm{II}}\left(\mathrm{OH}_{2}\right)(\mathrm{bpy})_{2}(\mathrm{py})\right]^{2+}$ with two equiv. of cerium(IV) ammonium nitrate (CAN: $\left.\mathrm{Ce}^{\mathrm{IV}}\right)$ [Eq. (4)] [33]. Since then, a number of high-valent metal-oxo complexes have been synthesized by the successive electron-transfer oxidation of metal complexes by two equiv. of oxidants (electron acceptors) with $\mathrm{H}_{2} \mathrm{O}$ as an oxygen source of the oxo ligands [34-41].

$$
\begin{aligned}
& \mathrm{Mn}^{\mathrm{III}}+\mathrm{H}_{2} \mathrm{O}-2 \mathrm{e}^{-}-2 \mathrm{H}^{+} \rightarrow \mathrm{Mn}^{\mathrm{V}}(\mathrm{O}) \\
& {\left[\mathrm{Ru}^{\mathrm{II}}\left(\mathrm{OH}_{2}\right)(\mathrm{bpy})_{2}(\text { py })\right]^{2+}+2 \mathrm{Ce}^{\mathrm{IV}} \rightarrow\left[\mathrm{Ru}^{\mathrm{IV}}(\mathrm{O})(\mathrm{bpy})_{2}(\mathrm{py})\right]^{2+}+2 \mathrm{Ce}^{\mathrm{III}}+2 \mathrm{H}^{+}}
\end{aligned}
$$


As mentioned above, high-valent metal-oxo complexes $\left(\mathrm{M}^{(\mathrm{n}+2)+}(\mathrm{O})\right)$ can oxidize a variety of substrates $(\mathrm{S})$, accompanied by regeneration of metal complexes $\left(\mathrm{M}^{\mathrm{n}+}\right)$. Therefore, $\mathrm{M}^{\mathrm{n}+}$ complexes have been used as efficient catalysts for the oxygenation of substrates $(\mathrm{S})$ to yield oxygenated products $(\mathrm{SO})$ via an electron-transfer oxidation of $\mathrm{M}^{\mathrm{n}+}$ by an electron acceptor (A) with $\mathrm{H}_{2} \mathrm{O}$ as an oxygen source (Scheme 1, where an oxygen in $\mathrm{SO}$ derives from $\mathrm{H}_{2} \mathrm{O}$ ). Herein, we review the recent advances in the catalytic oxygenation of substrates, including water oxidation, by one-electron oxidants with metal complexes using water as an oxygen source by focusing on the optimization the catalytic activity.

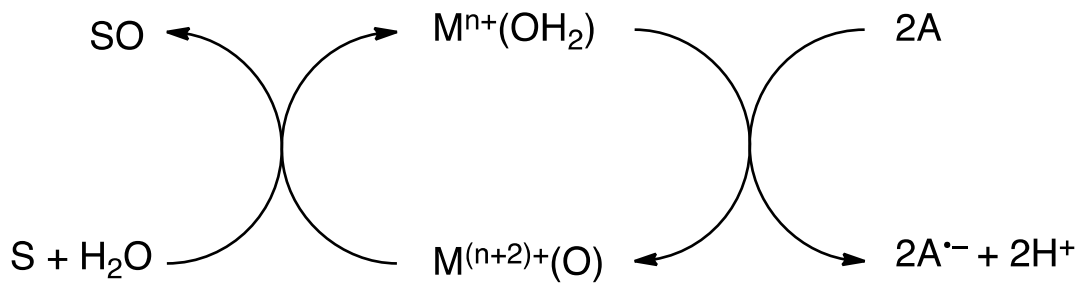

Scheme 1. Catalytic oxygenation of substrates (S) with high-valent metal-oxo complexes $\left(\mathrm{M}^{(\mathrm{n}+2)+}(\mathrm{O})\right)$ produced by electron-transfer oxidation of low-valent metal-aqua complexes $\left(\mathrm{M}^{\mathrm{n}+}\left(\mathrm{OH}_{2}\right)\right)$ with an electron acceptor $(\mathrm{A})$.

\section{Synthesis of metal-oxo and catalytic oxygenation of substrates by CAN}

The oxidation of metal complexes by CAN has shown the generation of high-valent metal-oxo complexes. For example, a bis-aqua $\mathrm{Ru}^{\mathrm{II}}$ complex, $\left[\mathrm{Ru}^{\mathrm{II}}(\mathrm{tpa})\left(\mathrm{H}_{2} \mathrm{O}\right)_{2}\right]\left(\mathrm{PF}_{6}\right)_{2}(\mathbf{1}$; tpa $=$ tris(2-pyridylmethyl)amine), was oxidized by two equiv. of CAN in water to yield $\left[\mathrm{Ru}^{\mathrm{IV}}(\mathrm{O})(\mathrm{tpa})\left(\mathrm{H}_{2} \mathrm{O}\right)\right]^{2+}[$ 2: Eq. (5)], accompanied by a rapid color change from deep green to brown at $\mathrm{pH} 2.0$ [42].

$\left[\mathrm{Ru}^{\mathrm{II}}(\mathrm{tpa})\left(\mathrm{H}_{2} \mathrm{O}\right)_{2}\right]^{2+}+2 \mathrm{Ce}^{\mathrm{IV}} \rightarrow\left[\mathrm{Ru}^{\mathrm{IV}}(\mathrm{O})(\mathrm{tpa})\left(\mathrm{H}_{2} \mathrm{O}\right)\right]^{2+}+2 \mathrm{Ce}^{\mathrm{III}}+2 \mathrm{H}^{+}$

A resonance Raman spectrum of the intermediate exhibited a signal at $806 \mathrm{~cm}^{-1}$, which was shifted to $764 \mathrm{~cm}^{-1}$ when $\mathrm{H}_{2}{ }^{18} \mathrm{O}$ was employed instead of $\mathrm{H}_{2}{ }^{16} \mathrm{O}$ owing to an isotopic 
shift of $\Delta v=42 \mathrm{~cm}^{-1}$ in agreement with the calculated value for the ${ }^{18} \mathrm{O}$ substitution in a $\mathrm{Ru}=\mathrm{O}$ harmonic oscillator $\left(\Delta v=40 \mathrm{~cm}^{-1}\right)$ [42]. This shift is the same as that observed for $\left[\mathrm{Ru}^{\mathrm{IV}}(\mathrm{O})(\text { bpy)})_{2} \text { (py) }\right]^{2+}$ from $792 \mathrm{~cm}^{-1}$ with $\mathrm{H}_{2}{ }^{16} \mathrm{O}$ to $752 \mathrm{~cm}^{-1}$ with $\mathrm{H}_{2}{ }^{18} \mathrm{O}$ and those for other $\mathrm{Ru}^{\mathrm{IV}}=\mathrm{O}$ complexes $[33,43,44]$. The X-ray photoelectron spectroscopy (XPS) measurements also confirmed the formation of the $\mathrm{Ru}^{\mathrm{IV}}=\mathrm{O}$ species [42]. The spin state of 2 was determined to be an intermediate $\operatorname{spin}(S=1)$ by the Evans ${ }^{1} \mathrm{H}$ NMR method [45].

$\left[\mathrm{Ru}^{\mathrm{II}}(\mathrm{tpa})\left(\mathrm{H}_{2} \mathrm{O}\right)_{2}\right]\left(\mathrm{PF}_{6}\right)_{2}$ (1) acts as an efficient catalyst for the oxygenation of cyclohexene by CAN at room temperature to yield only adipic acid, which is an eightelectron oxidized product of cyclohexene [42]. The catalytic turnover number (TON) was 2560 [42]. When the reaction was conducted in $\mathrm{H}_{2}{ }^{18} \mathrm{O},{ }^{18} \mathrm{O}$ was completely incorporated into adipic acid as revealed by the molecular ion peak of adipic acid at $m / z=155$ $\left([\mathrm{M}+\mathrm{H}]^{+}\right)$, which is 8 units higher than the mass number of adipic acid in $\mathrm{H}_{2}{ }^{16} \mathrm{O}$ [42]. This confirmed that all the oxygen atoms in adipic acid derived from water.

The catalytic cycle of the eight-electron oxidation of cyclohexene by CAN with $\mathbf{1}$ is shown in Scheme 2. 1 is oxidized by two equiv. of $\mathrm{CAN}$ to produce the $\mathrm{Ru}^{\mathrm{IV}}(\mathrm{O})$ species

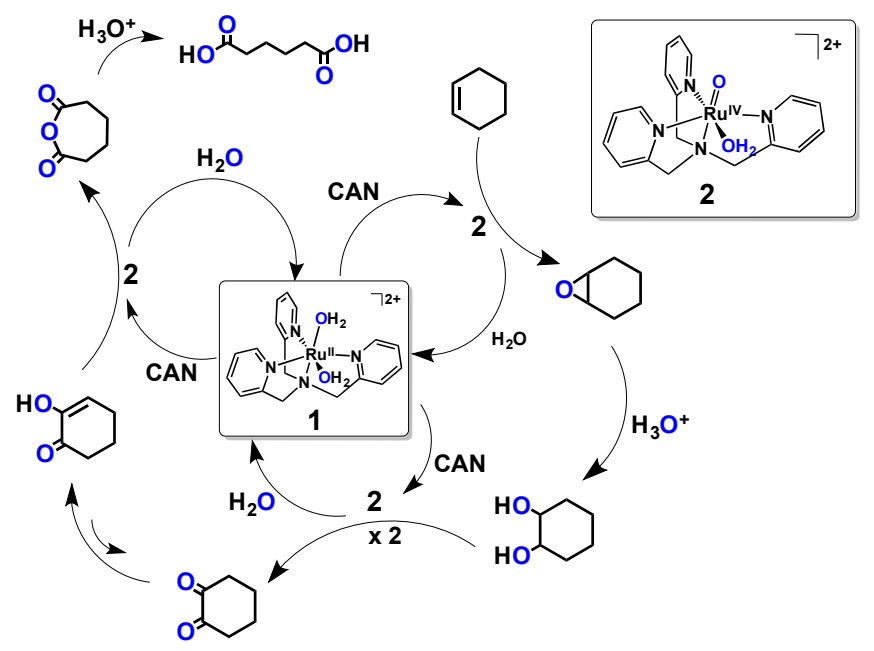

Scheme 2. Eight-electron oxidation of cyclohexene to adipic acid with $\left[\mathrm{Ru}^{\mathrm{IV}}(\mathrm{O})(\mathrm{tpa})\left(\mathrm{H}_{2} \mathrm{O}\right)\right]^{2+}(2)$ produced by electron-transfer oxidation of $\left[\mathrm{Ru}^{\mathrm{II}}(\operatorname{tpa})\left(\mathrm{H}_{2} \mathrm{O}\right)_{2}\right]^{2+}$ (1) with CAN. Reprinted with permission from Ref. [42]. Copyright 2008, WILEY-VCH Verlag GmbH \& Co. KGaA, Weinheim. 
(2), which transfers oxygen atom to cyclohexene to produce cyclohexene oxide [42]. Under acidic conditions, cyclohexene oxide is hydrolyzed to produce cyclohexane-1,2diol, which is further oxidized by two equiv. of 2 to produce cyclohexane-1,2-dione [42]. The subsequent Baeyer-Villiger-like oxidation gives an acid anhydride, and a final hydrolysis under strong acidic conditions yields adipic acid [46].

A water-soluble styrene derivative, sodium styrene-4-sulfonate was also oxidized by CAN with 1 to produce 4-(1,2-dihydroxyethyl)benzenesulfonate, which is the product of an acid-catalyzed ring-opening reaction of the corresponding epoxide [42]. In the presence of 8 equiv. of CAN, the water-soluble styrene derivative was fully oxidized to yield the corresponding benzoic acid and formic acid via the diol and benzaldehyde intermediates as shown in Fig. 1 [42]. The stepwise oxidation of the styrene derivative by 2 up to the eight-electron oxidation is shown in Scheme 3 [42]. A water-soluble sodium 4-sulfonate-1-ethylbenzene underwent four-electron oxidation to afford the

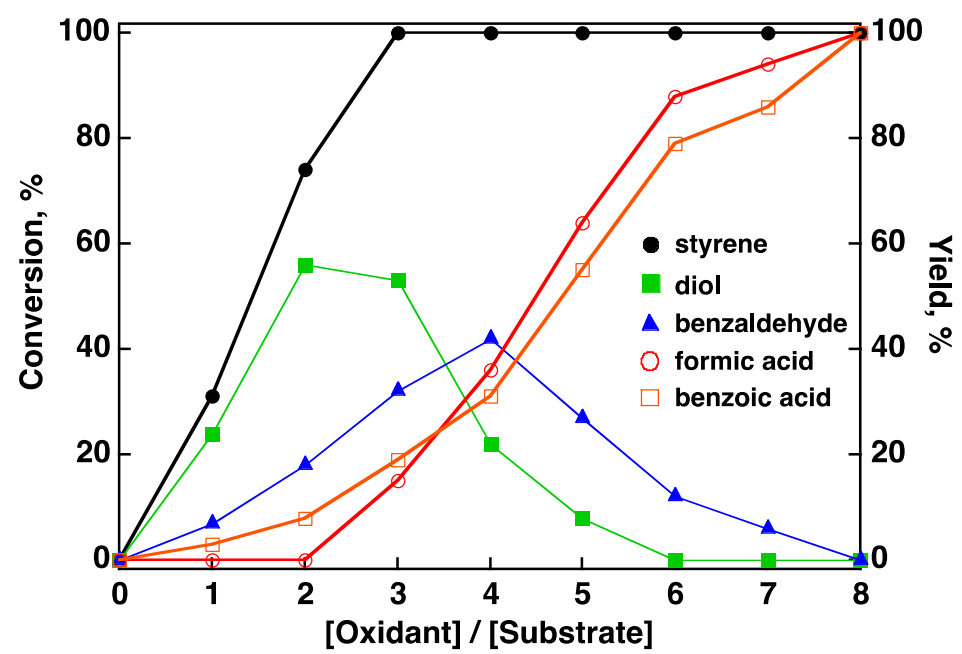

Fig. 1. Plots of conversion (only black circles) and yields (other colored marks) of oxidized products of styrene-4-sulfonate in the catalytic oxidation by CAN with $\left[\mathrm{Ru}^{\mathrm{II}}(\mathrm{tpa})\left(\mathrm{H}_{2} \mathrm{O}\right)_{2}\right]\left(\mathrm{PF}_{6}\right)_{2}(\mathbf{1})$ in water vs the initial ratio of CAN to styrene. Reprinted with permission from Ref. [42]. Copyright 2008, WILEY-VCH Verlag GmbH \& Co. KGaA, Weinheim. 


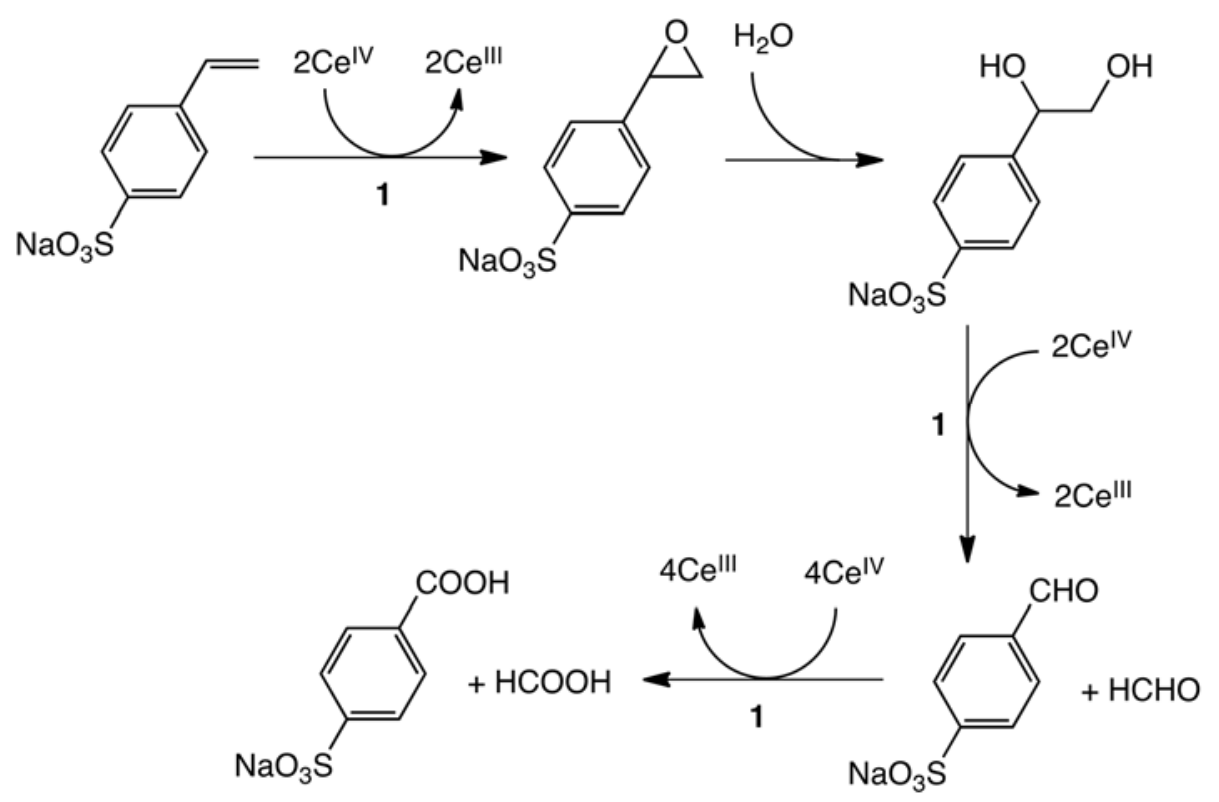

Scheme 3. Stepwise eight-electron oxidation of sodium styrene-4-sulfonate with $\left[\mathrm{Ru}^{\mathrm{IV}}(\mathrm{O})(\mathrm{tpa})\left(\mathrm{H}_{2} \mathrm{O}\right)\right]^{2+}(2)$ produced by electron-transfer oxidation of $\left[\mathrm{Ru}^{\mathrm{II}}(\operatorname{tpa})\left(\mathrm{H}_{2} \mathrm{O}\right)_{2}\right]^{2+}$ (1) with two equivalents of CAN.

corresponding acetophenone derivative selectively via hydrogen atom (H-atom) abstraction from $\mathrm{C}-\mathrm{H}$ bond of the ethyl group by 2 [42].

As demonstrated above, aqua complexes having a water molecule as a ligand are generally required to be oxidized to obtain the high-valent metal-oxo complexes. However, a high-valent metal-oxo complex was generated using a coordinatively saturated metal complex that is a hexa-coordinated ruthenium(II) complex having tpa and bpy as chelating ligands, $\left[\mathrm{Ru} \mathrm{u}^{\mathrm{II}}(\mathrm{tpa})(\mathrm{bpy})\right]^{2+}(\mathbf{3})$, which is stabilized by two chelating ligands without aqua ligand [47]. The electron-transfer oxidation of $\mathbf{3}$ by two equiv. of CAN afforded the corresponding $\mathrm{Ru}(\mathrm{IV})$-oxo complex, $\left[\mathrm{Ru}^{\mathrm{IV}}(\mathrm{O})\left(\mathrm{H}^{+} \text {tpa }\right)(\mathrm{bpy})\right]^{3+}(4)$, with water as an oxygen source [47]. The crystal structure of the cation part of $\mathbf{4}$ is depicted in Fig. 2, where the tpa ligand partially dissociates to be in a facial tridentate fashion and the uncoordinated pyridine moiety is protonated [47]. The bond length of the $\mathrm{Ru}=\mathrm{O}$ bond is 1.771(4) $\AA$, which is in the range of the values of other $\mathrm{Ru}(\mathrm{IV})$-oxo complexes $[36,44,48,49]$. The resonance Raman spectrum of $\mathbf{4}$ exhibited the $v\left(\mathrm{Ru}={ }^{16} \mathrm{O}\right)$ peak at 805 


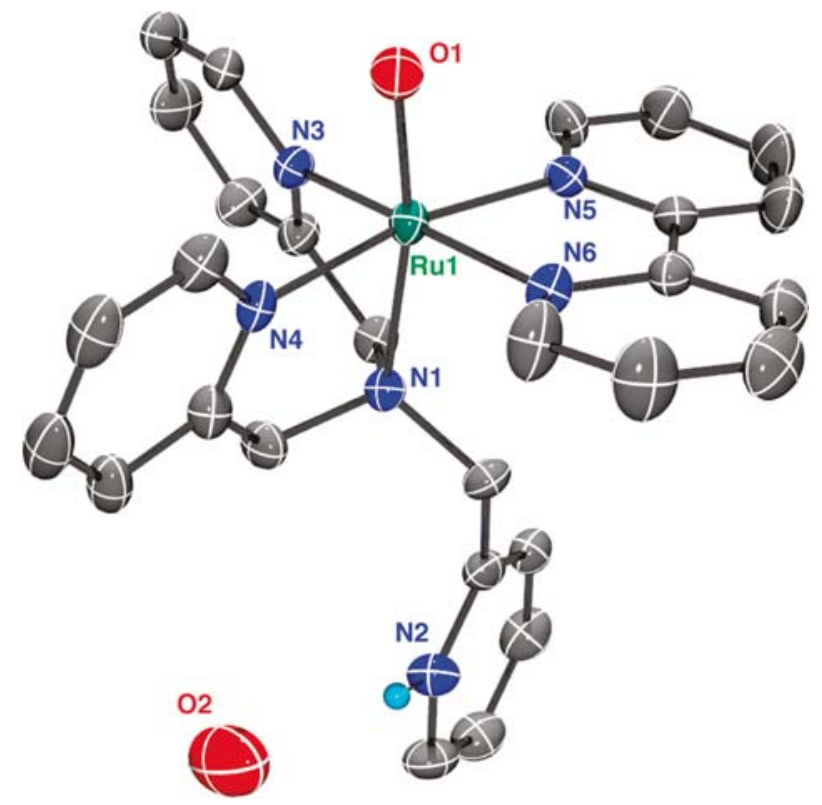

Fig. 2. ORTEP drawing of the cation moiety of $\left[\mathrm{Ru}^{\mathrm{IV}}(\mathrm{O})\left(\mathrm{H}^{+} \mathrm{TPA}\right)(\mathrm{bpy})\right]\left(\mathrm{PF}_{6}\right)_{3}$ (4) using $50 \%$ probability thermal ellipsoids with numbering scheme for the heteroatoms. Hydrogen atoms are omitted for clarity except the hydrogen on the uncoordinated pyridine nitrogen $\left(\mathrm{N}_{2}\right)$. $\mathrm{O} 2$ represents the water molecule of crystallization. Reprinted with permission from Ref. [47]. Copyright 2011, American Chemical Society.

$\mathrm{cm}^{-1}$, which shifted to $764 \mathrm{~cm}^{-1}$ for $v\left(\mathrm{Ru}={ }^{18} \mathrm{O}\right)$, as observed in the case of $\left[\mathrm{Ru}^{\mathrm{IV}}(\mathrm{O})(\mathrm{tpa})\left(\mathrm{H}_{2} \mathrm{O}\right)\right]^{2+}$ (vide supra) [47]. The spin state of $\mathbf{4}$ was determined to be an intermediate-spin $(S=1)$ by the Evans ${ }^{1} \mathrm{H}$ NMR method $[45,47]$.

The $\mathrm{Ru}(\mathrm{IV})$-oxo complex (4) was able to oxygenate alkylbenzene derivatives such as cumene in acetonitrile at room temperature via $\mathrm{H}$-atom abstraction from cumene, followed by the dissociation of the alcohol products from the oxygen-rebound complexes, $\mathrm{Ru}(\mathrm{III})$-alkoxo complexes, which were successfully detected by electrospray ionization mass spectrometry (ESI-MS) (Scheme 4) [47]. From the rate constants of cumene and cumene-d12, the kinetic isotope effect (KIE) was determined to be 12 for the H-atom abstraction step [47]. In the first step, H-atom transfer from cumene to $\mathbf{4}$ occurs to produce cumyl radical and a Ru(III)-hydroxo complex. The oxygen rebound between the cumyl 

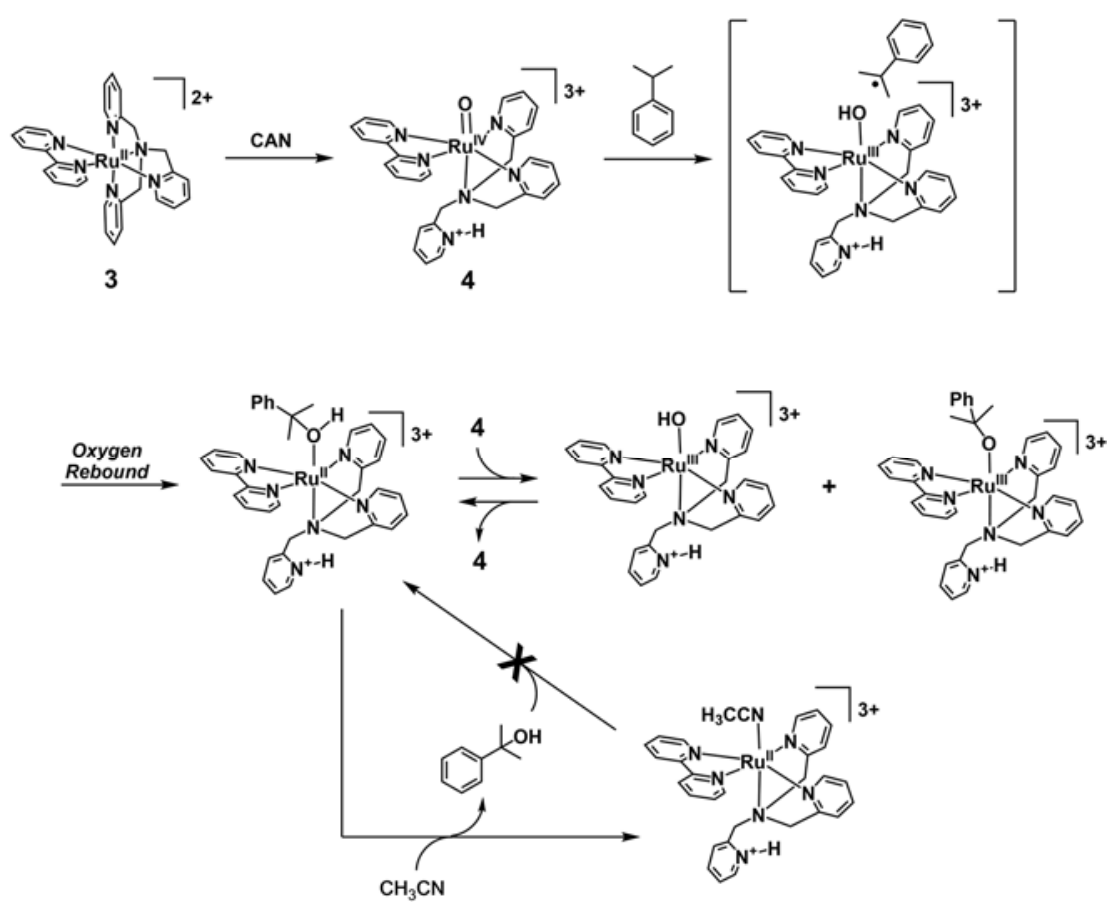

Scheme 4. Oxygen-rebound mechanism for oxygenation of cumene with $\left[\mathrm{Ru}^{\mathrm{IV}}(\mathrm{O})\left(\mathrm{H}^{+} \text {tpa }\right)(\mathrm{bpy})\right]^{3+} \quad$ (4) produced by electron-transfer oxidation of $\left[\mathrm{Ru}^{\mathrm{II}}(\mathrm{tpa})(\mathrm{bpy})\right]^{2+}(\mathbf{3})$ with $\mathrm{CAN}$ in water. Reprinted with permission from Ref. [47]. Copyright 2011, American Chemical Society.

radical species and the $\mathrm{Ru}(\mathrm{III})$-hydroxo complex affords the $\mathrm{Ru}(\mathrm{II})$-cumyl alcohol complex. The Ru(II)-cumyl alcohol complex is readily oxidized by 4 via H-atom transfer to produce the $\mathrm{Ru}(\mathrm{III})$-hydroxo complex and the $\mathrm{Ru}(\mathrm{III})$-alkoxo complex, which were detected by ESI-MS and EPR measurements [47]. The reverse reaction may also occur to reproduce the $\mathrm{Ru}(\mathrm{II})$-cumyl alcohol complex, from which cumyl alcohol slowly dissociates via ligand substitution with $\mathrm{CH}_{3} \mathrm{CN}$ to yield $\left[\mathrm{Ru}^{\mathrm{II}}\left(\mathrm{H}^{+} \text {tpa }\right)(\mathrm{bpy})\left(\mathrm{CH}_{3} \mathrm{CN}\right)\right]^{3+}$ and cumyl alcohol as the final products [47].

A $\mathrm{Ru}^{\mathrm{II}}$-aqua complex having a pentadentate $N, N$-bis(2-pyridylmethyl)- $N$-(6carboxylato-2-pyridylmethyl)amine (6- $\mathrm{COO}^{-}$-tpa) monoanion was converted to a sevencoordinate pentagonal-bipyramidal $\mathrm{Ru}^{\mathrm{IV}}$-oxo complex, $\left[\mathrm{Ru}^{\mathrm{IV}}(\mathrm{O})\left(6-\mathrm{COO}^{-}-\mathrm{TPA}\right)\left(\mathrm{H}_{2} \mathrm{O}\right)\right]^{+}$ (5 in Fig. 3), by the electron-transfer oxidation of the $\mathrm{Ru}^{\mathrm{II}}$-aqua complex with two equiv. of CAN in an acidic aqueous solution [50]. The spin state of 5 was determined to be $S=$ 
0 with the observation of a diamagnetic ${ }^{1} \mathrm{H}$ NMR spectrum of 5 [50]. A Ru ${ }^{\mathrm{IV}}$-oxo complex, $\left[\mathrm{Ru}^{\mathrm{IV}}(\mathrm{O})(\mathrm{N} 4 \mathrm{Py})\left(\mathrm{H}_{2} \mathrm{O}\right)\right]^{+}$(6 in Fig. 3, N4Py $=N, N$-bis(2-pyridylmethyl)- $N$-bis(2pyridyl)methylamine), produced by the electron-transfer oxidation of $\left[\mathrm{Ru}^{\mathrm{II}}\left(\mathrm{OH}_{2}\right)(\mathrm{N} 4 \mathrm{Py})\right]^{2+}$ with two equiv. of $\mathrm{CAN}$ in an acidic aqueous solution, also exhibited a diamagnetic ${ }^{1} \mathrm{H}$ NMR spectrum on the basis of the $S=0$ spin state, due to a

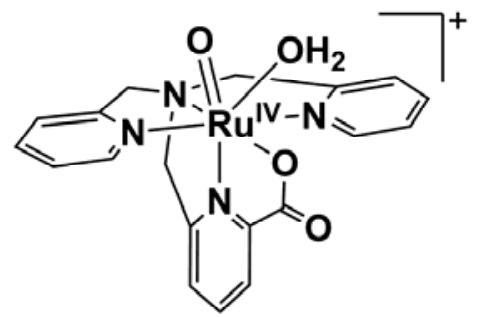

5

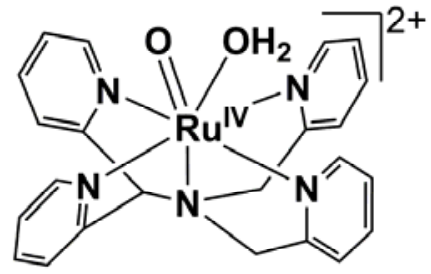

6

Fig. 3. Molecular structures of high-valent $\mathrm{Ru}^{\mathrm{IV}}(\mathrm{O})$ complexes with 6-COO--TPA (5) and N4Py (6). Reprinted with permission from Ref. [51]. Copyright 2012, Royal Society of Chemistry.

putative seven-coordinate pentagonal-bipyramidal structure, which should be stabilized by hydrogen bonding with solvent water molecules [51].

The $\mathrm{Ru}^{\mathrm{IV}}(\mathrm{O})$ complexes $(2,5$ and 6) exhibited no significant difference in the reactivity for the catalytic oxidation of methanol and 1-propanaol in an acidic aqueous solutions, judging from the similar reaction rates and the activation parameters despite the difference in the spin state ( $S=0$ for $\mathbf{5}$ and $\mathbf{6}, S=1$ for $\mathbf{2})$ [51]. Thus, the spin state of the $\mathrm{Ru}^{\mathrm{IV}}(\mathrm{O})$ complexes has no significant relevance to the reactivity in the transition structure, because the latter may have a different spin state owing to spin crossover along the reaction path $[52,53]$. The logarithm of the rate constants of oxidation of 1-propanol by $\mathbf{2}, \mathbf{5}$ and $\mathbf{6}$ shows linear relationships with the one-electron reduction potentials of the $\mathrm{Ru}^{\mathrm{IV}}(\mathrm{O})$ complexes, as demonstrated in Fig. 4. Thus, the slight difference in the reaction rates and the activation parameters results from the difference in the electron accepting ability of the three $\mathrm{Ru}^{\mathrm{IV}}(\mathrm{O})$ complexes rather than the difference in the spin state [51]. 


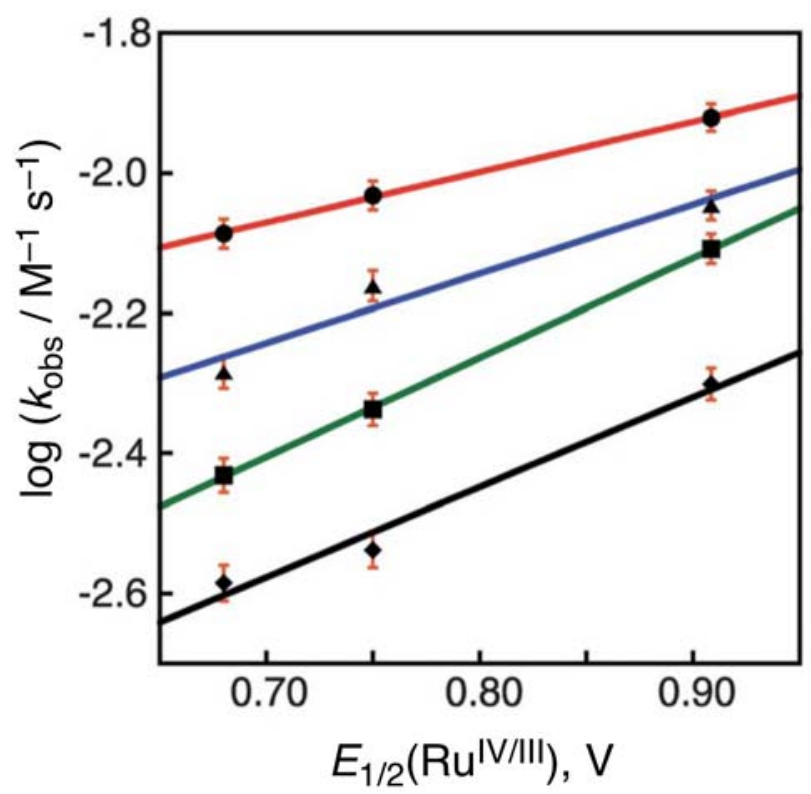

Fig. 4. Plots of $\log k_{\mathrm{obs}}$ for the oxidation of 1-propanol with $\mathrm{Ru}^{\mathrm{IV}}(\mathrm{O})$ complexes at various temperatures (at $308 \mathrm{~K}$, filled circles and red line; at $301 \mathrm{~K}$, filled triangles and blue line; at $288 \mathrm{~K}$, filled squares and green line; at $280 \mathrm{~K}$, filled rectangles and black line) against the one-electron reduction potentials (vs SCE) of the $\mathrm{Ru}^{\mathrm{IV}}(\mathrm{O})$ complexes $(+0.75 \mathrm{~V}$ for $\mathbf{2}$, $+0.68 \mathrm{~V}$ for $\mathbf{5},+0.91 \mathrm{~V}$ for 6). Reprinted with permission from Ref. [51]. Copyright 2012, Royal Society of Chemistry.

Iron(II) complexes, [(N4Py)Fe $\left.{ }^{\mathrm{II}}\left(\mathrm{CH}_{3} \mathrm{CN}\right)\right]\left(\mathrm{ClO}_{4}\right)_{2}$ and $\left[(\mathrm{Bn}-\mathrm{TPEN}) \mathrm{Fe}^{\mathrm{II}}(\mathrm{OTf})\right](\mathrm{OTf})$ $\left(\mathrm{Bn}-\mathrm{TPEN}=N\right.$-benzyl- $N, N^{\prime}, N^{\prime}$-tris(2-pyridylmethyl)ethane-1,2-diamine, OTf ${ }^{-}=$ $\mathrm{CF}_{3} \mathrm{SO}_{3}{ }^{-}$), were also converted to the corresponding $\mathrm{Fe}^{\mathrm{IV}}(\mathrm{O})$ complexes by the electrontransfer oxidation of the $\mathrm{Fe}^{\mathrm{II}}$ complexes with two equiv. of CAN [54]. Because $\mathrm{Fe}^{\mathrm{IV}}(\mathrm{O})$ complexes can oxygenate various substrates, $\left[(\mathrm{N} 4 \mathrm{Py}) \mathrm{Fe}^{\mathrm{II}}\left(\mathrm{CH}_{3} \mathrm{CN}\right)\right]\left(\mathrm{ClO}_{4}\right)_{2}$ and $[(\mathrm{Bn}-$ TPEN)Fe $\left.{ }^{\mathrm{II}}(\mathrm{OTf})\right](\mathrm{OTf})$ act as catalysts in oxygenation of substrates with CAN using water as an oxygen source [54]. A high-valent nonheme $\mathrm{Mn}^{\mathrm{IV}}=\mathrm{O}$ intermediate was also produced from its manganese(II) precursor, using CAN as a one-electron oxidant in either acetonitrile/water $(9: 1)$ or acetone/water $(9: 1)$ at $273 \mathrm{~K}[55]$. 


\section{Catalytic oxidation of water by CAN}

Ever since Meyer and co-workers reported the catalytic water oxidation by CAN to evolve $\mathrm{O}_{2}$ using "blue dimer", cis,cis-[(bpy $\left.)_{2}\left(\mathrm{H}_{2} \mathrm{O}\right) \mathrm{Ru}^{\mathrm{III}} \mathrm{ORu}{ }^{\mathrm{III}}\left(\mathrm{H}_{2} \mathrm{O}\right)(\mathrm{bpy})_{2}\right]^{4+}$, in 1982 [56,57], a huge number of metal complexes have been reported to catalyze water oxidation using CAN as an oxidant to evolve $\mathrm{O}_{2}$ [36-38,58-62]. Metal complexes with inorganic ligands, which are stable under water oxidation conditions, have been reported to act as robust water oxidation catalysts. The first example of such a water oxidation catalyst is a tetraruthenium complex with silicodecatungstate, $\left[\left\{\mathrm{Ru}_{4} \mathrm{O}_{4}(\mathrm{OH})_{2}\left(\mathrm{H}_{2} \mathrm{O}\right)_{4}\right\}(\gamma-\right.$ $\left.\left.\mathrm{SiW}_{10} \mathrm{O}_{36}\right)_{2}\right]^{10-}$, which catalyzes water oxidation with one-electron oxidants such as CAN and $\left[\mathrm{Ru}^{\mathrm{III}}(\mathrm{bpy})_{3}\right]^{3+}[63,64]$. A tetracobalt complex with phosphononatungstate, $\left[\mathrm{Co} 4\left(\mathrm{H}_{2} \mathrm{O}\right)_{2}\left(\mathrm{PW}_{9} \mathrm{O}_{34}\right)_{2}\right]^{10-}$, has also been reported to act as an efficient and robust catalyst for photocatalytic water oxidation with $\left[\mathrm{Ru}^{\mathrm{III}}(\mathrm{bpy})_{3}\right]^{3+}$ as a one-electron oxidant [65].

Single-site ruthenium complexes with heteroundecatungstate, $\left[\mathrm{Ru}^{\mathrm{III}}\left(\mathrm{H}_{2} \mathrm{O}\right) \mathrm{SiW}_{11} \mathrm{O}_{39}\right]^{5-}(7)[66,67]$ and $\left[\mathrm{Ru}^{\mathrm{III}}\left(\mathrm{H}_{2} \mathrm{O}\right) \mathrm{GeW}_{11} \mathrm{O}_{39}\right]^{5-}(8)$ (Fig. 5), were also reported to act as efficient and robust oxidation catalysts for water oxidation by CAN [68]. The time course of the water oxidation by CAN with 7 is shown in Fig. 6, where the decrease in the concentration of CAN coincides with the $\mathrm{O}_{2}$ evolution. A nearly
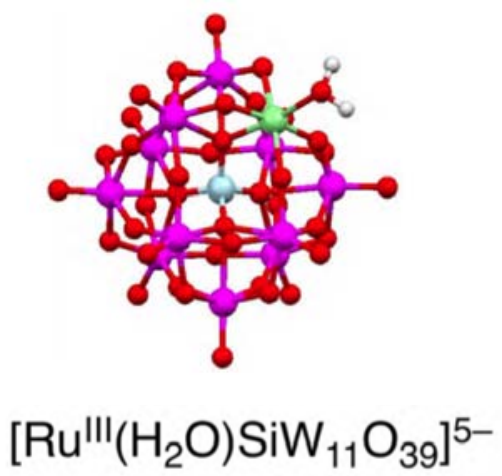
7

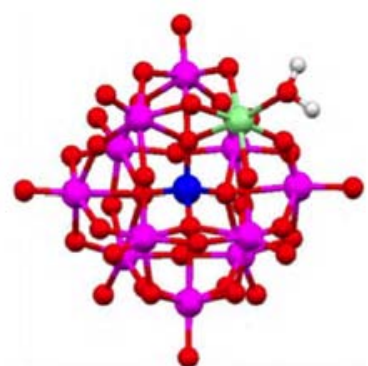

$\left[\mathrm{Ru}^{\mathrm{III}}\left(\mathrm{H}_{2} \mathrm{O}\right) \mathrm{GeW}_{11} \mathrm{O}_{39}\right]^{5-}$ 8

Fig. 5. Structures of Ru polyoxometalates ( 7 and $\mathbf{8}$ ). $\mathrm{Ru}$, light green; $\mathrm{W}$, purple; $\mathrm{O}$, red; H, white; Si, light blue; Ge, deep blue. Reprinted with permission from Ref. [68]. Copyright 2011, American Chemical Society. 


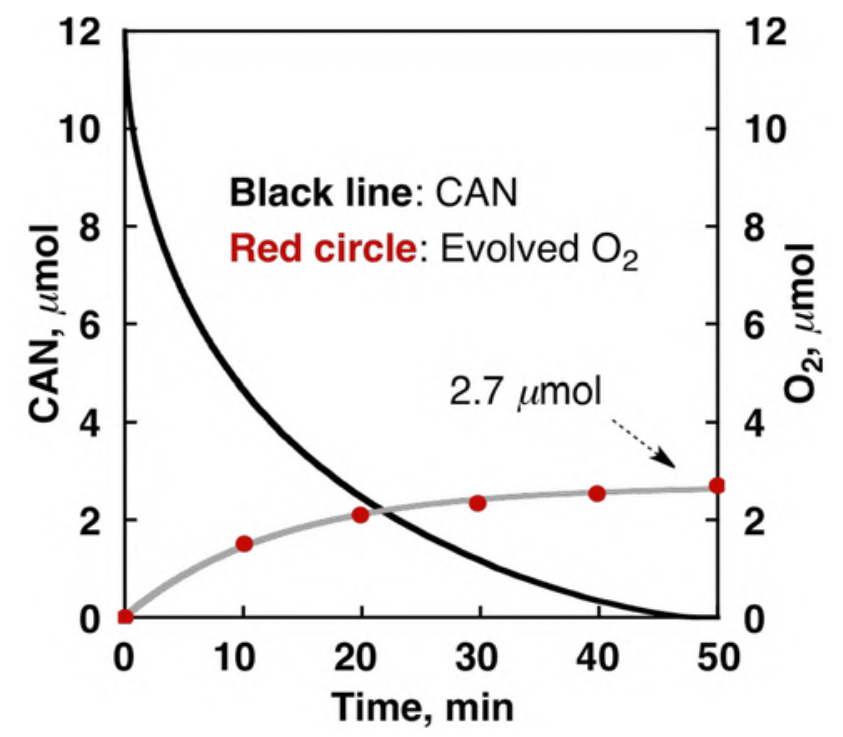

Fig. 6. Time course of the amount of evolved oxygen (red) and CAN (-) in the reaction of $7\left(3.0 \times 10^{-4} \mathrm{M}\right)$ with CAN $\left(6.0 \times 10^{-3} \mathrm{M}\right)$ in an aqueous solution containing $0.10 \mathrm{M}$ $\mathrm{HNO}_{3}$ at $298 \mathrm{~K}$. Reprinted with permission from Ref. [68]. Copyright 2011, American Chemical Society.

stoichiometric amount of $\mathrm{O}_{2}(2.7 \mu \mathrm{mol})$ was finally produced by using $12 \mu \mathrm{mol}$ of CAN [68]. GC-MS analysis of oxygen evolved during water oxidation using $\mathrm{H}_{2}{ }^{18} \mathrm{O}$ confirmed that the oxygen source of evolved oxygen was water [68].

The Pourbaix diagrams (plots of $E_{1 / 2} \mathrm{vs} \mathrm{pH}$ ) for 7 and $\mathbf{8}$ in the range of $0<\mathrm{pH}<8$ in water (Fig. 7) indicate that the (L) $\mathrm{Ru}^{\mathrm{III}}-\mathrm{OH}_{2}$ complex $\left(\mathrm{L}=\left[\mathrm{SiW}_{11} \mathrm{O}_{39}\right]^{8-}\right.$ for 7 and $\left[\mathrm{GeW}_{11} \mathrm{O}_{39}\right]^{8-}$ for 8 ) is oxidized to the $(\mathrm{L}) \mathrm{Ru}^{\mathrm{IV}}-\mathrm{OH}_{2}$ complex at $\mathrm{pH} 1$ at an applied potential between 0.62 and $0.90 \mathrm{~V}$ (vs SCE) without losing proton when the $E_{1 / 2}$ value remains constant with the change in $\mathrm{pH}$ around 1 [68]. The $(\mathrm{L}) \mathrm{Ru}^{\mathrm{IV}}-\mathrm{OH}_{2}$ complex is further oxidized to the $(\mathrm{L}) \mathrm{Ru}^{\mathrm{V}}=\mathrm{O}$ complex at $\mathrm{pH} 1$ at an applied potential above $0.90 \mathrm{~V}$ with removal of two protons, when the $E_{1 / 2}$ value decreases with increasing $\mathrm{pH}$ from 1 with a slope of $118 \mathrm{mV}$ [68]. Thus, 7 and $\mathbf{8}$ are expected to be oxidized by CAN $\left(E_{1 / 2}=\right.$ 1.21 $\mathrm{V}$ vs SCE at $\mathrm{pH} 1.0)$ [69] to the $(\mathrm{L}) \mathrm{Ru}^{\mathrm{V}}=\mathrm{O}$ complexes [68]. 

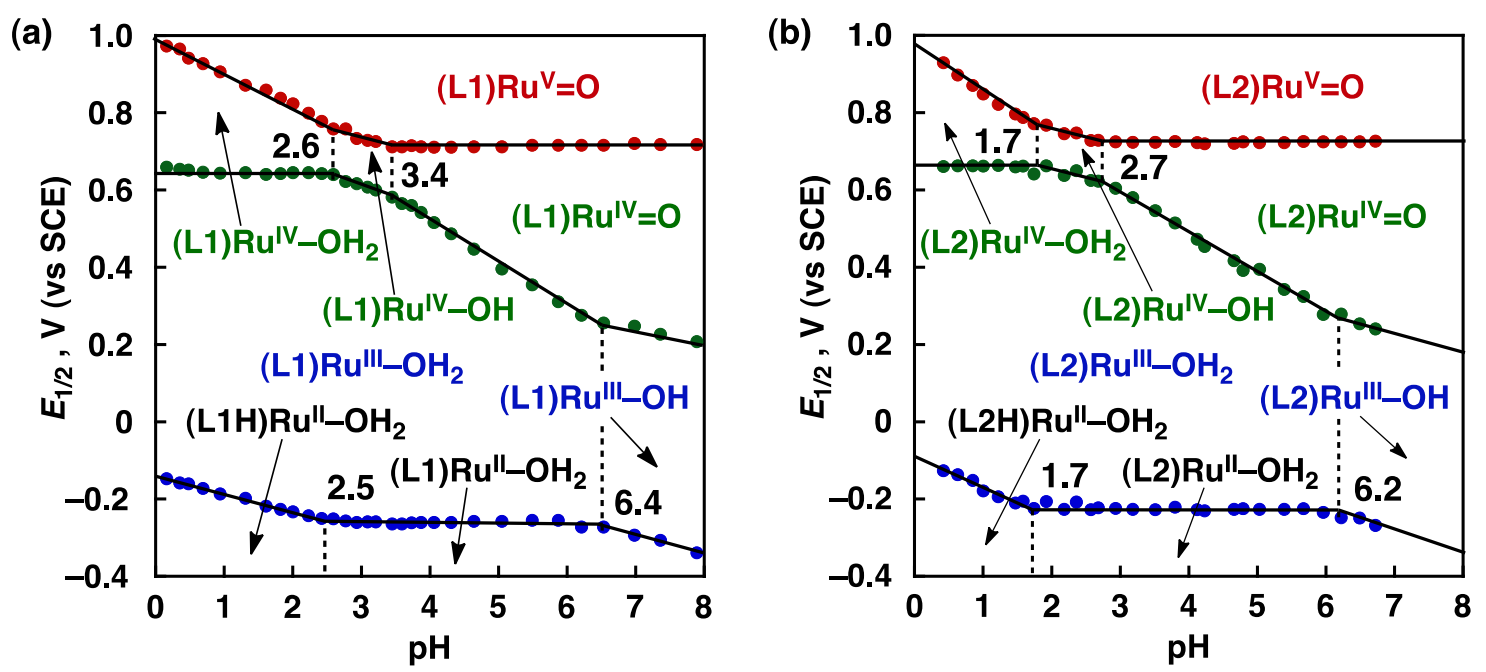

Fig. 7. Pourbaix diagrams for (a) 7 and (b) 8. The blue, green, and red points correspond to the $\mathrm{Ru}(\mathrm{III}) / \mathrm{Ru}(\mathrm{II}), \mathrm{Ru}(\mathrm{IV}) / \mathrm{Ru}(\mathrm{III})$, and $\mathrm{Ru}(\mathrm{V}) / \mathrm{Ru}(\mathrm{IV})$ redox potentials, respectively. All the four $\mathrm{p} K_{\mathrm{a}}$ values are shown by the vertical dashed lines. L1 and L2 denote the ligand of 7 and 8, respectively. Reprinted with permission from Ref. [68]. Copyright 2011, American Chemical Society.

The catalytic mechanism of water oxidation by $\mathrm{CAN}$ with $\left[(\mathrm{L}) \mathrm{Ru}^{\mathrm{III}}-\mathrm{OH}_{2}\right]^{5-}(\mathbf{7}$ and $\mathbf{8})$ is shown in Scheme 5 [68]. [(L) $\left.\mathrm{Ru}^{\mathrm{III}}-\mathrm{OH}_{2}\right]^{5-}$ is oxidized by one equiv. of CAN to produce $\left[(\mathrm{L}) \mathrm{Ru}^{\mathrm{IV}}-\mathrm{OH}_{2}\right]^{4-}$, which is further oxidized by one equiv. of CAN to afford $\left[(\mathrm{L}) \mathrm{Ru}^{\mathrm{V}}=\mathrm{O}\right]^{5-}$, accompanied by removal of two protons [68]. The formation of $\left[(\mathrm{L}) \mathrm{Ru}^{\mathrm{V}}=\mathrm{O}\right]^{5-}$ was

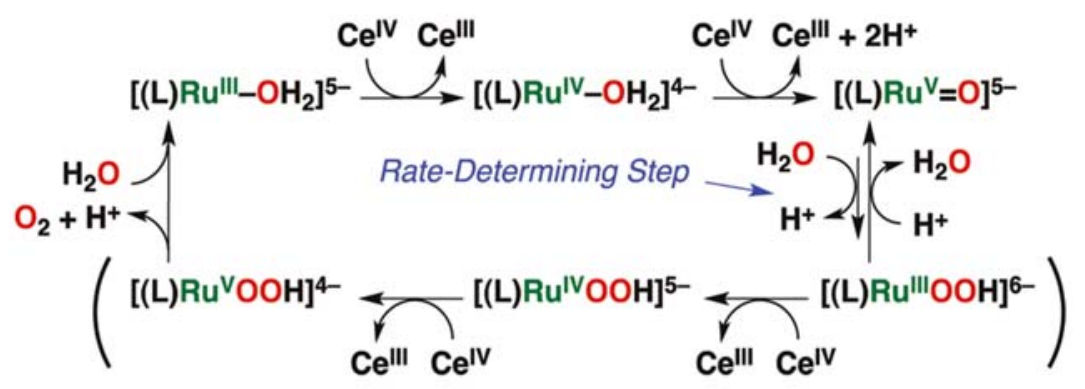

Scheme 5. Mechanism of catalytic four-electron oxidation of water to oxygen using ruthenium(V)-oxo complexes with heteroundecatungstate $\left(\left[(\mathrm{L}) \mathrm{Ru}^{\mathrm{V}}=\mathrm{O}\right]^{5-}\right)$ produced by electron-transfer oxidation of $\left[(\mathrm{L}) \mathrm{Ru}^{\mathrm{III}}-\mathrm{OH}_{2}\right]^{5-}$ with CAN. Reprinted with permission from Ref. [68]. Copyright 2011, American Chemical Society. 
confirmed by the EPR $\left(g_{\perp}=2.1\right.$ and $\left.g / /=1.9 \sim 2.0\right)$ and resonance Raman $\left(\nu\left(\mathrm{Ru}={ }^{16} \mathrm{O}\right)=\right.$ $800 \mathrm{~cm}^{-1}$ ) spectra [68]. The water oxidation rate slightly increased with increasing $\mathrm{pH}$ and the rate also increased with increasing concentration of CAN to approach a constant value [68]. Such a saturation behavior of the water oxidation rate with increasing $\mathrm{pH}$ and concentration of CAN indicates that the nucleophilic attack of $\mathrm{H}_{2} \mathrm{O}$ to $\left[(\mathrm{L}) \mathrm{Ru}^{\mathrm{V}}=\mathrm{O}\right]^{5-}$ to produce $\left[(\mathrm{L}) \mathrm{Ru}^{\mathrm{III}}-\mathrm{OOH}\right]^{6-}$ is the rate-determining step, which competes with the back reaction from the $\left[(\mathrm{L}) \mathrm{Ru}^{\mathrm{III}}-\mathrm{OOH}\right]^{6-}$ to $\left[(\mathrm{L}) \mathrm{Ru}^{\mathrm{V}}=\mathrm{O}\right]^{5-}$ via the $\mathrm{O}-\mathrm{O}$ bond cleavage as shown in Scheme 5, where the subsequent fast electron-transfer oxidation of $\left[(\mathrm{L}) \mathrm{Ru}^{\mathrm{III}}-\mathrm{OOH}\right]^{6-}$ with CAN leads to the oxygen evolution [68]. The catalytic reactivity of 8 was 1.5 times higher than that of 7 [68]. The higher catalytic reactivity of 8 may result from the electronwithdrawing effect of germanium (core atom of the polyoxometalato ligand), as indicated by the smaller $\mathrm{p} K_{\mathrm{a}}$ value of $\mathbf{8}(6.2)$ as compared with 7 (6.4) [68].

A series of homogeneous iron complexes containing water-coordination sites with organic ligands also exhibited catalytic activity for water oxidation by CAN [70-73]. However, the ligand dissociation of the iron complexes (9 and 10 in Fig. 8) was observed under acidic conditions, and the dissociated organic ligands were oxidized by CAN to yield $\mathrm{CO}_{2}$ [73]. Fig. 9 shows the time courses of $\mathrm{CO}_{2}$ and $\mathrm{O}_{2}$ evolution with $\mathbf{9}, \mathbf{1 0}$, and

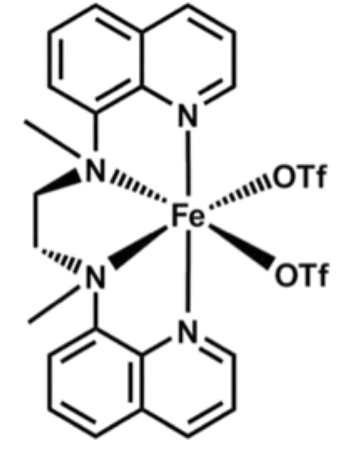

$\mathrm{Fe}(\mathrm{BQEN})(\mathrm{OTf})_{2}(\mathbf{9})$

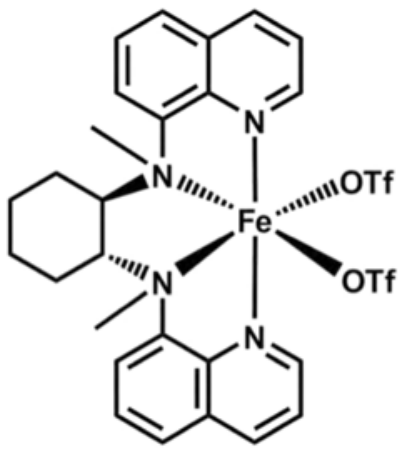

$\mathrm{Fe}(\mathrm{BQCN})(\mathrm{OTf})_{2}(\mathbf{1 0})$

Fig. 8. Iron complexes (9 and 10) used as catalysts for water oxidation by CAN. Reprinted with permission from Ref. [73]. Copyright 2013, American Chemical Society. 

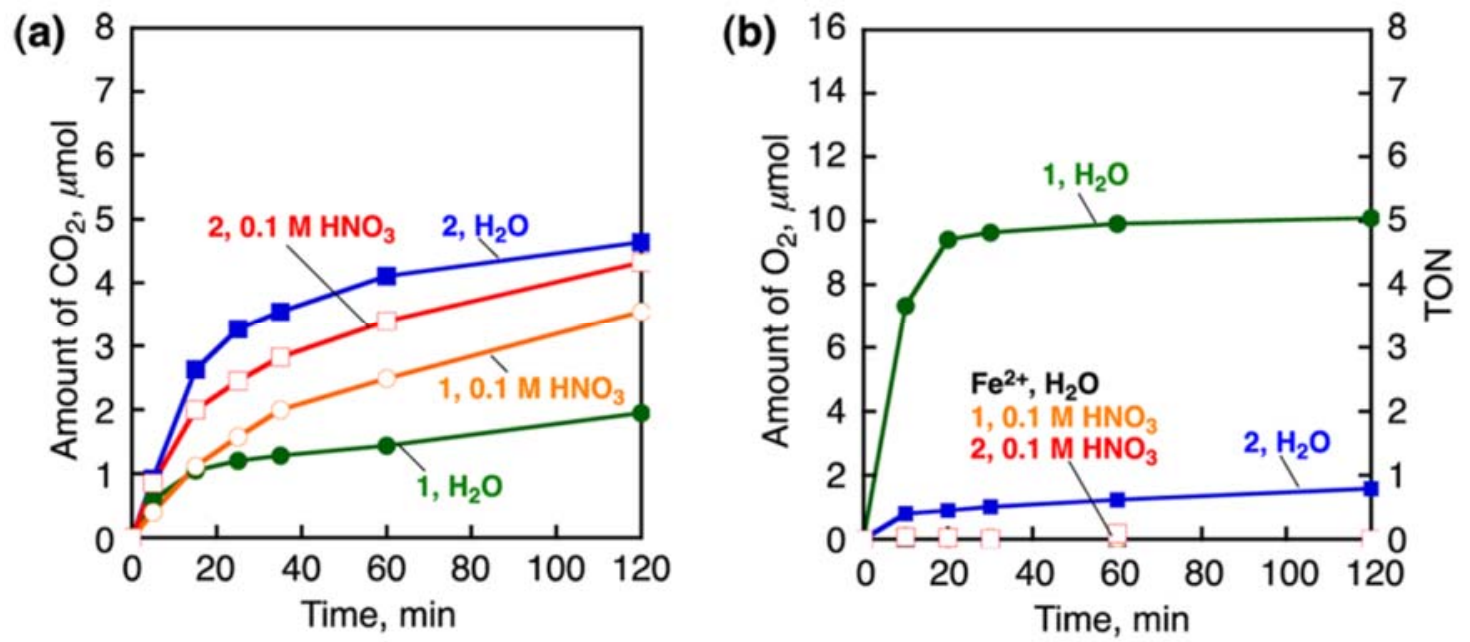

Fig. 9. Time courses of (a) $\mathrm{CO}_{2}$ evolution and (b) $\mathrm{O}_{2}$ evolution in the catalytic water oxidation by CAN $(0.10 \mathrm{M})$ with $\mathbf{9}, 10$ and $\mathrm{FeSO}_{4}(1.0 \mathrm{mM})$ in a non-buffered aqueous solution and in an aqueous solution containing $0.10 \mathrm{M} \mathrm{HNO}_{3}(2.0 \mathrm{~mL})$. Reprinted with permission from Ref. [73]. Copyright 2013, American Chemical Society.

$\mathrm{FeSO}_{4}$ performed in a non-buffered aqueous solution and in an aqueous solution containing $0.10 \mathrm{M} \mathrm{HNO}_{3}$ [73]. $\mathrm{CO}_{2}$ evolution was observed with both 9 and 10 even at the initial reaction stage in the non-buffered solution as well as in the $0.10 \mathrm{M} \mathrm{HNO}_{3}$ aqueous solution. 9 was converted to a $\mathrm{Fe}^{\mathrm{IV}}(\mathrm{O})$ complex during the water oxidation in competition with the ligand oxidation [73].

When four equiv. of CAN were added to a non-buffered aqueous solution of $\mathbf{9}$, the absorption band at $760 \mathrm{~nm}$ due to the $\mathrm{Fe}^{\mathrm{IV}}=\mathrm{O}$ complex immediately appeared and then decreased gradually as the $\mathrm{O}_{2}$ evolution occurred and finally ceased. These results indicate that the iron complexes act as the true homogeneous catalyst for water oxidation by $\mathrm{CAN}$ at low $\mathrm{pHs}$ via formation of the $\mathrm{Fe}^{\mathrm{IV}}(\mathrm{O})$ complex in competition with the ligand dissociation and oxidation [73].

The oxygen exchange between the $\mathrm{Fe}^{\mathrm{IV}}(\mathrm{O})$ complex and $\mathrm{H}_{2} \mathrm{O}$ was examined using labeled water [73]. First, the reaction of 9 with two equiv. of CAN was performed in $\mathrm{H}_{2}{ }^{16} \mathrm{O}$ to produce $\mathrm{Fe}^{\mathrm{IV}}={ }^{16} \mathrm{O}$ and then two equiv. of $\mathrm{CAN}$ in $\mathrm{H}_{2}{ }^{18} \mathrm{O}(98 \%$ 
${ }^{18} \mathrm{O}$-enriched) was added to the resulting solution to detect the isotopes of evolved $\mathrm{O}_{2}$. The isotope ratio of the evolved $\mathrm{O}_{2}$ was ${ }^{16} \mathrm{O}^{16} \mathrm{O}(27.3 \%):{ }^{18} \mathrm{O}^{16} \mathrm{O}(47.7 \%)$ : ${ }^{18} \mathrm{O}^{18} \mathrm{O}(25.0 \%)$, which agrees with the theoretical ratio $(26.5: 50.0: 23.5)$ calculated by assuming that the oxygen exchange between $\mathrm{Fe}^{\mathrm{IV}}={ }^{16} \mathrm{O}$ and $\mathrm{H}_{2}{ }^{18} \mathrm{O}$ is much faster than the oxygen evolution under the reaction conditions (vide infra) [73]. The oxygen exchange between $\mathrm{Fe}^{\mathrm{IV}}={ }^{16} \mathrm{O}$ and $\mathrm{H}_{2}{ }^{18} \mathrm{O}(48.5 \%)$ may occur rapidly via $\mathrm{Fe}^{\mathrm{IV}}\left({ }^{16} \mathrm{OH}\right)\left({ }^{18} \mathrm{OH}\right)$ following coordination of $\mathrm{H}_{2}{ }^{18} \mathrm{O}$ to produce the same amount of $\mathrm{Fe}^{\mathrm{IV}}={ }^{16} \mathrm{O}$ and $\mathrm{Fe}^{\mathrm{IV}}={ }^{18} \mathrm{O}$ as shown in Scheme $6 \mathrm{~b}$ and $6 \mathrm{c}$. Both $\mathrm{Fe}^{\mathrm{IV}}={ }^{16} \mathrm{O}$ and $\mathrm{Fe}^{\mathrm{IV}}={ }^{18} \mathrm{O}$ are further oxidized by $\mathrm{CAN}$ in $\mathrm{H}_{2}{ }^{16} \mathrm{O}(51.5 \%)$ and $\mathrm{H}_{2}{ }^{18} \mathrm{O}(48.5 \%)$ to produce $\mathrm{O}_{2}$ with the theoretical isotope ratio of ${ }^{16} \mathrm{O}^{16} \mathrm{O}:{ }^{18} \mathrm{O}^{16} \mathrm{O}:{ }^{18} \mathrm{O}^{18} \mathrm{O}=26.5$ : $50.0: 23.5$ (Scheme 6a-d) [73].

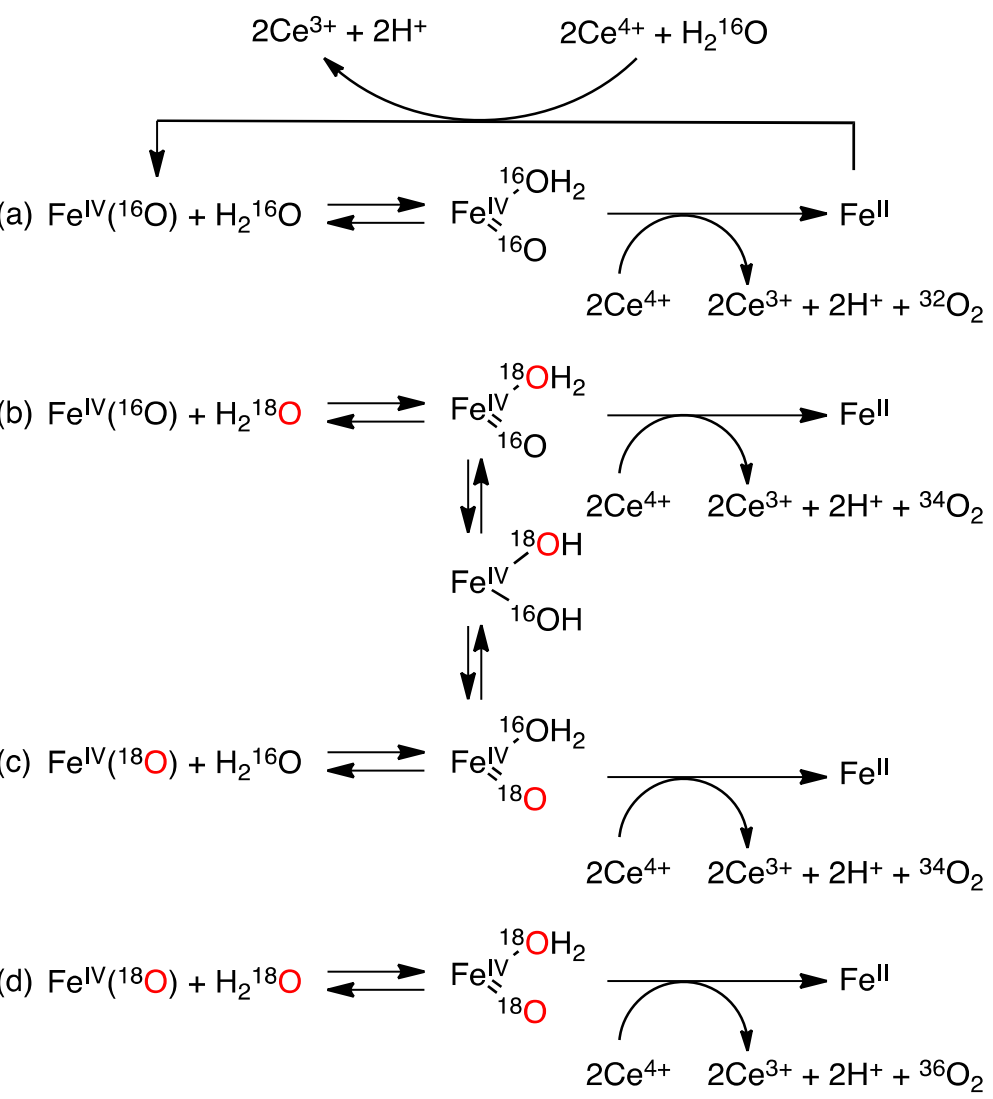

Scheme 6. Oxygen exchange mechanism of $\mathrm{Fe}^{\mathrm{IV}}\left({ }^{16 / 18} \mathrm{O}\right)$ with $\mathrm{H}_{2}{ }^{16 / 18} \mathrm{O}$ in the catalytic four-electron oxidation of water by CAN with non-heme iron complexes (9 and 10). Reprinted with permission from Ref. [73]. Copyright 2013, American Chemical Society. 
Further mechanistic insight has been reported for the catalytic water oxidation by $\mathrm{CAN}$ with a nonheme iron complex $\alpha$-[(mcp)Fe $\left.{ }^{\mathrm{II}}\left(\mathrm{CF}_{3} \mathrm{SO}_{3}\right)_{2}\right]\left(\mathrm{mcp}=\left(N, N^{\prime}-\right.\right.$ dimethyl- $N, N^{\prime}$-bis(2-pyridylmethyl)-1,2-cis-diaminocyclohexane), in which an intermediate was characterized by cold-spray ionization high resolution mass spectrometry and resonance Raman spectroscopy, and formulated as $\left[(\mathrm{mcp}) \mathrm{Fe}^{\mathrm{IV}}(\mathrm{O})(\mu-\mathrm{O}) \mathrm{Ce}^{\mathrm{IV}}\left(\mathrm{NO}_{3}\right)_{3}\right]^{+}$, which is an inner-sphere complex to be formed in the catalytic water oxidation by CAN [74]. Such binding of metal ion acting as a strong Lewis acid was reported for $\mathrm{Fe}-\mathrm{O}-\mathrm{Sc}$ and $\mathrm{Mn}-\mathrm{O}-\mathrm{Sc}$ units $[75,76]$. The binding of metal ions to the metal-oxo moiety was reported to enhance the reactivity of the metal-oxo complexes in various oxygenation reactions of substrates [13,14,77-89]. However, binding of metal ions acting as strong Lewis acids to the metal-peroxo complexes (e.g., (TMC)Fe $\mathrm{TII}^{\mathrm{III}}\left(\mu, \eta^{2}: \eta^{2}-\mathrm{O}_{2}\right)-\mathrm{M}^{\mathrm{n}+}, \mathrm{M}^{\mathrm{n}+}=$ $\mathrm{Sc}^{3+}, \mathrm{Y}^{3+}$, and $\mathrm{Lu}^{3+}$ ) was reported to result in deceleration of the oxidation to evolve $\mathrm{O}_{2}$ [90]. Thus, the acceleration effect of binding of a metal ion to the metal-oxo complex for the reduction should be well balanced with the deceleration effect of binding of a metal ion to the metal-peroxo complex for the oxidation to evolve $\mathrm{O}_{2}$, as observed for the role of $\mathrm{Ca}^{2+}$ ion in the oxygen evolving complex (OEC) of Photosystem II [29-32].

\section{Catalytic oxygenation of substrates by $\left[\mathrm{Ru}^{\mathrm{III}}(\mathrm{bpy})_{3}\right]^{3+}$}

Catalytic oxygenation of substrates was reported to occur using $\left[\mathrm{Ru}^{\mathrm{III}}(\mathrm{bpy})_{3}\right]^{3+}$, which is a weaker oxidant than CAN, water as an oxygen source, and manganese porphyrins $\left((\mathrm{P}) \mathrm{Mn}^{\mathrm{III}}\right)$ as catalysts (Scheme 7) [91]. Manganese porphyrins employed as catalysts are $\left[(\mathrm{TMP}) \mathrm{Mn}^{\mathrm{III}}\right]^{+}\left(\mathrm{TMP}^{2-}=5,10,15,20\right.$-tetrakis $(2,4,6-$ trimethylphenyl)porphyrin dianion), $\left[(\mathrm{TDCPP}) \mathrm{Mn}^{\mathrm{III}}\right]^{+}\left(\mathrm{TDCPP}^{2-}=5,10,15,20-\right.$ tetrakis(2,6-dichlorophenyl)porphyrin dianion), [(TMOPP) $\left.\mathrm{Mn}^{\mathrm{III}}\right]^{+}\left(\mathrm{TMOPP}^{2-}=\right.$ 5,10,15,20-tetrakis-(2,4,6-trimethoxyphenyl)porphyrin dianion), and 
$\left[(\mathrm{DTMPD}) \mathrm{Mn}^{\mathrm{III}}{ }_{2}\right]^{2+}\left(\mathrm{DTMPD}^{4-}=\right.$ di-trimesitylporphyrin dibenzofuran tetraanion $)$ in Fig. 10 [91].

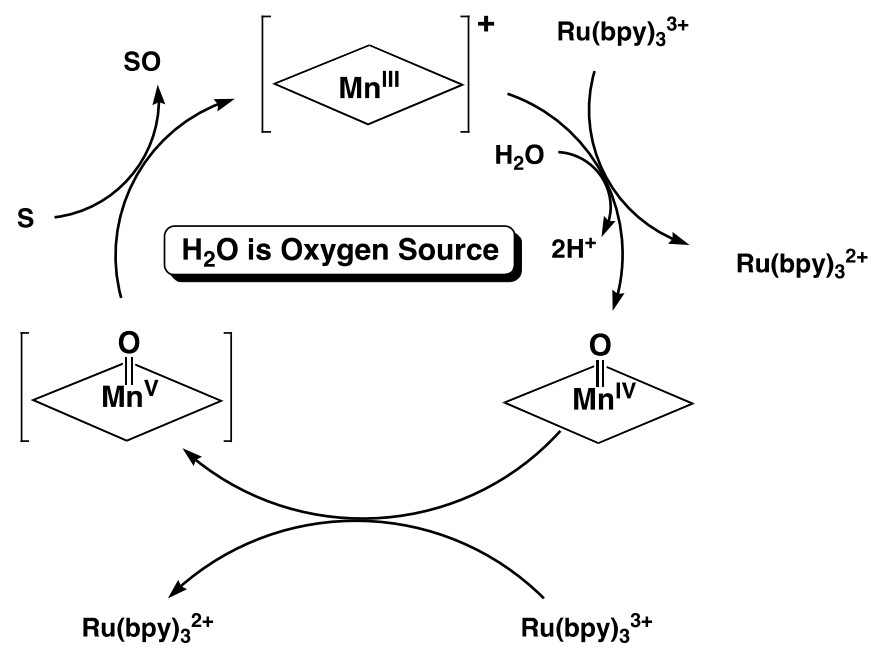

Scheme 7. Catalytic oxygenation of substrates $(\mathrm{S})$ with $\mathrm{Mn}^{\mathrm{V}}(\mathrm{O})$ porphyrins produced by electron-transfer oxidation of $\mathrm{Mn}^{\mathrm{III}}$ porphyrins with $\left[\mathrm{Ru}(\mathrm{bpy})_{3}\right]^{3+}$. Reprinted with permission from Ref. [91]. Copyright 2012, WILEY-VCH Verlag GmbH \& Co. KGaA, Weinheim.

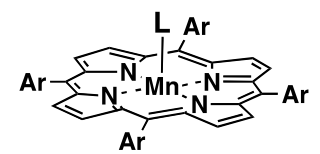

(P)Mn ${ }^{\text {III }}$ (L) (P: Porphyrin, L: Axial Ligand)

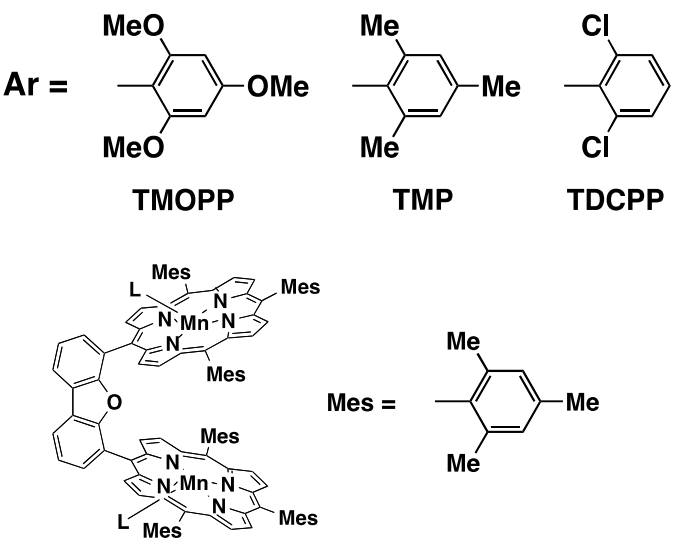

Fig. 10. Manganese porphyrins employed for catalytic oxygenation of substrates by $\left[\mathrm{Ru}(\mathrm{bpy})_{3}\right]^{3+}$. Reprinted with permission from Ref. [91]. Copyright 2012, WILEY-VCH Verlag GmbH \& Co. KGaA, Weinheim. 
The catalytic oxygenation of substrates by $\left[\mathrm{Ru}^{\mathrm{III}}(\mathrm{bpy})_{3}\right]^{3+}$ with $(\mathrm{P}) \mathrm{Mn}^{\mathrm{III}}$ occurs via the $\mathrm{Mn}^{\mathrm{V}}(\mathrm{O})$ intermediate $\left((\mathrm{P}) \mathrm{Mn}^{\mathrm{V}}(\mathrm{O})\right)$, which is produced by successive electron transfer from $(\mathrm{P}) \mathrm{Mn}^{\mathrm{III}}$ to two equiv. of $\left[\mathrm{Ru}^{\mathrm{III}}(\mathrm{bpy})_{3}\right]^{3+}$ with $\mathrm{H}_{2} \mathrm{O}$, accompanied by removal of two protons from an aqua ligand (Scheme 7) [91]. $(\mathrm{P}) \mathrm{Mn}^{\mathrm{V}}(\mathrm{O})$ oxygenates substrates, accompanied by regeneration of $(\mathrm{P}) \mathrm{Mn}^{\mathrm{III}}$ to complete the catalytic cycle in Scheme 7 [91]. Olefins such as styrene and cyclohexene were oxygenated with $\left[\mathrm{Ru}(\mathrm{bpy})_{3}\right]^{3+}$ and $\mathrm{H}_{2} \mathrm{O}$ in the presence of a catalytic amount of $(\mathrm{P}) \mathrm{Mn}^{\mathrm{III}}$ to produce epoxides, which were converted to the corresponding diols by hydrolysis and the diols were further oxidized to aldehydes as shown in Scheme 8 [91]. Ethylbenzene was also oxygenated to produce the corresponding alcohol [91]. The epoxidation of styrene and the hydroxylation of ethylbenzene with $\left[\mathrm{Ru}^{\mathrm{III}}(\mathrm{bpy})_{3}\right]^{3+}$ in the presence of $95 \%{ }^{18} \mathrm{O}$-water containing a catalytic amount of (P)Mn ${ }^{\mathrm{III}}$ afforded the corresponding epoxide and alcohol with $90 \%$ incorporation of ${ }^{18} \mathrm{O}$ in the oxygenated products [91]. Thus, the oxygen source in the oxygenated products in the $(\mathrm{P}) \mathrm{Mn}^{\mathrm{III}}$-catalyzed electron-transfer oxygenation of substrates with $\left[\mathrm{Ru}^{\mathrm{III}}(\mathrm{bpy})_{3}\right]^{3+}$ was confirmed to be water in the mixed solvent $\left(\mathrm{MeCN} / \mathrm{H}_{2} \mathrm{O}\right)[91]$.

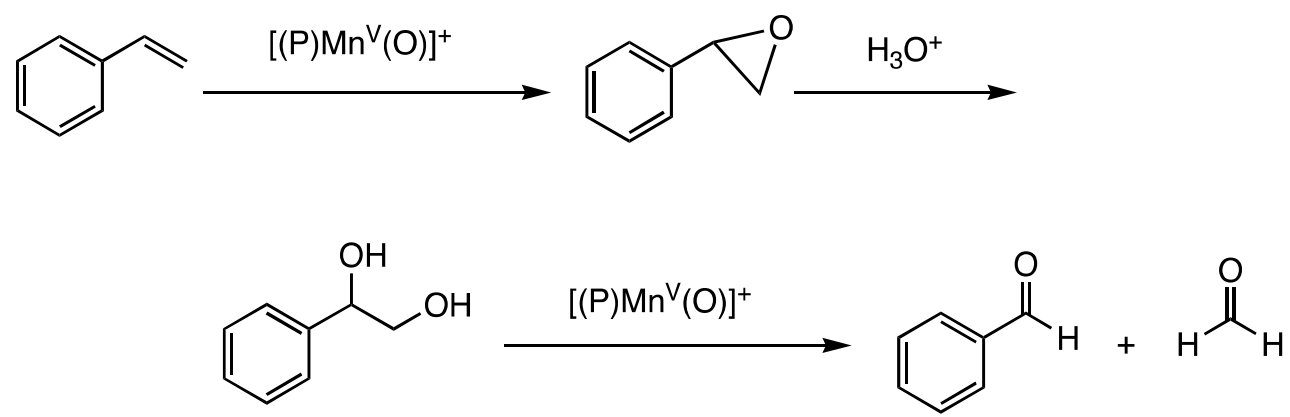

Scheme 8. Oxidation of styrene with $\left[(\mathrm{P}) \mathrm{Mn}^{\mathrm{V}}(\mathrm{O})\right]^{+}$produced by electron-transfer oxidation of $(\mathrm{P}) \mathrm{Mn}^{\mathrm{III}}$ with $\left[\mathrm{Ru}(\mathrm{bpy})_{3}\right]^{3+}$ to yield the corresponding diols by hydrolysis and further oxidation to aldehydes. Reprinted with permission from Ref. [91]. Copyright 2012, WILEY-VCH Verlag GmbH \& Co. KGaA, Weinheim. 
The turnover numbers (TONs) of catalytic oxygenation of styrene and cyclohexene by $\left[\mathrm{Ru}^{\mathrm{III}}(\text { bpy })_{3}\right]^{3+}$ with various manganese porphyrins are listed in Table 1. TON increases with increasing the first and second one-electron oxidation potentials of $(\mathrm{P}) \mathrm{Mn}^{\mathrm{III}}$, such as TMOPP $(0.95$ and $1.11 \mathrm{~V})<\mathrm{TMP}(1.02$ and $1.20 \mathrm{~V})$ $<$ TDCPP (1.20 and $1.48 \mathrm{~V})$ [91]. In the case of [(DTMPD) $\mathrm{Mn}^{\mathrm{III}}{ }_{2} \mathrm{Cl}_{2}$ ], the TON values are significantly smaller than those of the corresponding monomer, [(TMP) $\left.\mathrm{Mn}^{\mathrm{III}} \mathrm{Cl}\right]$, because the $\mathrm{Mn}^{\mathrm{V}}(\mathrm{O})$ species derived from [(DTMPD) $\mathrm{Mn}^{\mathrm{III}}{ }_{2} \mathrm{Cl}_{2}$ ] may be produced inside the diporphyrin cavity to prevent the interaction with substrates [91].

Table 1. Turnover numbers $(\mathrm{TON})$ in oxygenation of cyclohexene $\left(5.0 \times 10^{-3} \mathrm{M}\right)$ and styrene $\left(5.0 \times 10^{-3} \mathrm{M}\right)$ with $\left[\mathrm{Ru}^{\mathrm{III}}(\mathrm{bpy})_{3}\right]^{3+}\left(1.0 \times 10^{-2} \mathrm{M}\right)$, catalyzed by various $(\mathrm{P}) \mathrm{Mn}^{\mathrm{III}}$ in $\mathrm{CD}_{3} \mathrm{CN} / \mathrm{D}_{2} \mathrm{O}(9: 1 \mathrm{v} / \mathrm{v})$ at $298 \mathrm{~K}$. Reprinted with permission from Ref. [91]. Copyright 2012, WILEY-VCH Verlag GmbH \& Co. KGaA, Weinheim.

\begin{tabular}{|c|c|c|c|}
\hline \multirow{2}{*}{ catalyst } & \multirow{2}{*}{$\mathrm{Ar}$} & \multicolumn{2}{|c|}{ TON } \\
\hline & & cyclohexene & styrene \\
\hline (TMP)Mn ${ }^{\mathrm{III}} \mathrm{Cl}$ & & 130 & 20 \\
\hline$\left[(\mathrm{TMP}) \mathrm{Mn}^{\mathrm{III}}\left(\mathrm{H}_{2} \mathrm{O}\right)_{2}\right]\left(\mathrm{PF}_{6}\right)$ & & 170 & 65 \\
\hline (TDCPP) $\mathrm{Mn}^{\mathrm{III}} \mathrm{Cl}$ & & 160 & 70 \\
\hline$\left[(\mathrm{TDCPP}) \mathrm{Mn}^{\mathrm{III}}\left(\mathrm{H}_{2} \mathrm{O}\right)_{2}\right]\left(\mathrm{PF}_{6}\right)$ & & 210 & 85 \\
\hline (TMOPP) $\mathrm{Mn}^{\mathrm{III}} \mathrm{Cl}$ & & 80 & trace \\
\hline$\left[(\mathrm{TMOPP}) \mathrm{Mn}^{\mathrm{III}}\left(\mathrm{H}_{2} \mathrm{O}\right)_{2}\right]\left(\mathrm{PF}_{6}\right)$ & & 110 & 35 \\
\hline (DTMPD) $\mathrm{Mn}^{\mathrm{III}}{ }_{2} \mathrm{Cl}_{2}$ & & 20 & trace \\
\hline$\left[(\mathrm{DTMPD}) \mathrm{Mn}^{\mathrm{III}} 2\left(\mathrm{H}_{2} \mathrm{O}\right)_{2}\right]\left(\mathrm{PF}_{6}\right)_{2}$ & & 80 & 20 \\
\hline
\end{tabular}


The rate constants $\left(k_{\mathrm{et}}\right)$ of electron transfer from $(\mathrm{P}) \mathrm{Mn}^{\mathrm{III}}(\mathrm{OH})$ to $\left[\mathrm{Ru}^{\mathrm{III}}(\mathrm{bpy})_{3}\right]^{3+}$ to produce $(\mathrm{P}) \mathrm{Mn}^{\mathrm{IV}}(\mathrm{O})$ and electron transfer from $(\mathrm{P}) \mathrm{Mn}^{\mathrm{IV}}(\mathrm{O})$ to $\left[\mathrm{Ru}^{\mathrm{III}}(\mathrm{bpy})_{3}\right]^{3+}$ to produce $\left[(\mathrm{P}) \mathrm{Mn}^{\mathrm{V}}(\mathrm{O})\right]^{+}$were well evaluated in light of the Marcus theory of adiabatic outer-sphere electron transfer [Eq. (6)],

$k_{\mathrm{et}}=Z \exp \left[-(\lambda / 4)\left(1+\Delta G^{0}{ }_{\mathrm{et}} / \lambda\right)^{2} / k_{\mathrm{B}} T\right]$

where $Z$ is the collision frequency taken as $1 \times 10^{11} \mathrm{M}^{-1} \mathrm{~s}^{-1}$ and $\lambda$ is the reorganization energy of electron transfer [92,93]. Fig. 11 shows the driving force dependence of $\log k_{\text {et }}$ fitted by Eq. (6). The best-fit value of $\lambda$ for electron transfer from (TMP) $\mathrm{Mn}^{\mathrm{III}}(\mathrm{OH})$ and (TMP) $\mathrm{Mn}^{\mathrm{IV}}(\mathrm{O})$ to one-electron oxidants was determined to be $24 \mathrm{kcal} \mathrm{mol}^{-1}(1.04 \mathrm{eV})$ [Fig. 11 (1)] [91]. The larger $\lambda$ value [35

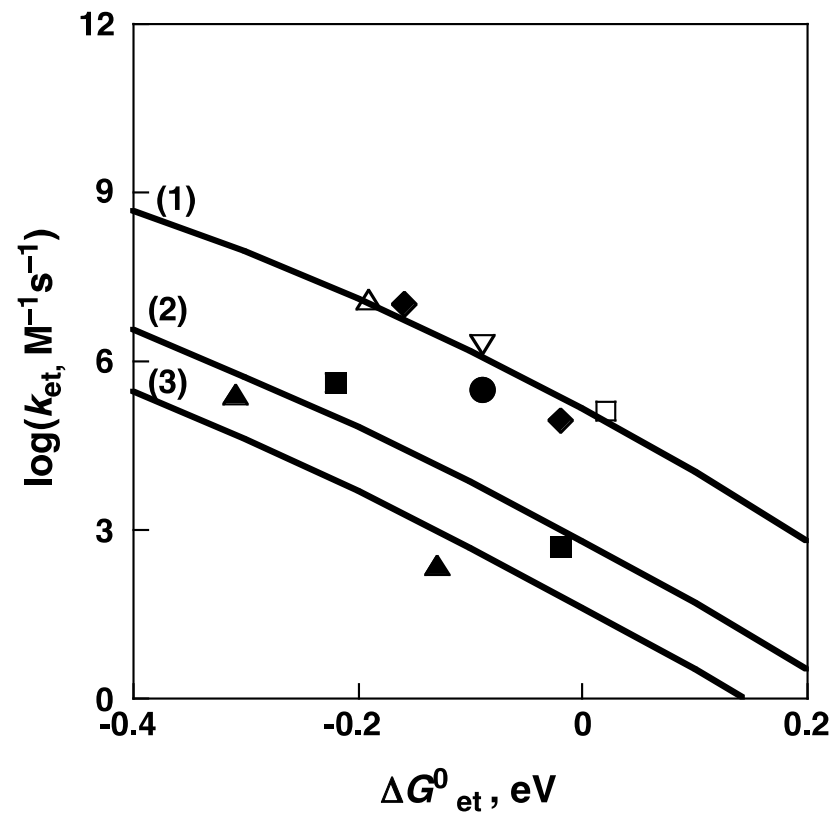

Fig. 11. Dependence of $\log \left(k_{\mathrm{et}}, \mathrm{M}^{-1} \mathrm{~s}^{-1}\right)$ on $\Delta G^{0}$ et for the electron-transfer oxidation of (TMP) $\mathrm{Mn}^{\mathrm{III}}(\mathrm{OH})$ with various oxidants $\left\{\left[\mathrm{Fe}\left(5-\mathrm{NO}_{2} \text { phen }\right)_{3}\right]\left(\mathrm{PF}_{6}\right)_{3}(\triangle),\left[\mathrm{Ru}(\mathrm{bpy})_{3}\right]\left(\mathrm{PF}_{6}\right)_{3}\right.$ $(\diamond),\left[\mathrm{Fe}(5-\mathrm{Cl}-\mathrm{phen})_{3}\right]\left(\mathrm{PF}_{6}\right)_{3}(\nabla)$ and $\left.\left[\mathrm{Fe}(\mathrm{bpy})_{3}\right]\left(\mathrm{PF}_{6}\right)_{3}(\square)\right\}$ and of $\left[(\mathrm{TMP}) \mathrm{Mn}^{\mathrm{III}}\left(\mathrm{H}_{2} \mathrm{O}\right)_{2}\right]^{+}$ (O), (TMP)Mn ${ }^{\mathrm{III}}(\mathrm{Cl})(\boldsymbol{\square})$ and $(\mathrm{DTMPD}) \mathrm{Mn}^{\mathrm{III}}{ }_{2}(\mathrm{Cl})_{2}(\boldsymbol{\Delta})$ with $\left[\mathrm{Ru}(\mathrm{bpy})_{3}\right]^{3+}$ in $\mathrm{MeCN}$ containing $\mathrm{H}_{2} \mathrm{O}(6.5 \mathrm{mM})$. The solid line represents the fitting to Eqn. (6) with (1) $\lambda=24$ $\mathrm{kcal} \mathrm{mol}^{-1}$ (2) $\lambda=35 \mathrm{kcal} \mathrm{mol}^{-1}$ and (3) $\lambda=40 \mathrm{kcal} \mathrm{mol}^{-1}$. Reprinted with permission from Ref. [91]. Copyright 2012, WILEY-VCH Verlag GmbH \& Co. KGaA, Weinheim. 
$\left.\mathrm{kcal} \mathrm{mol}^{-1}(1.52 \mathrm{eV})\right]$ was obtained for the first and second electron transfer from $\left[(\mathrm{TMP}) \mathrm{Mn}^{\mathrm{III}} \mathrm{Cl}\right]$ to $\left[\mathrm{Ru}^{\mathrm{III}}(\mathrm{bpy})_{3}\right]^{3+} \quad[$ Fig. 11 (2)] [91]. The $\lambda$ value of [(DTMPD) $\left.\mathrm{Mn}^{\mathrm{III}}{ }_{2} \mathrm{Cl}_{2}\right]$ [40 kcal mol${ }^{-1}(1.73 \mathrm{eV})$ in Fig. 11 (3)] was also large [91]. The large $\lambda$ values may result from the reorganization of the $\mathrm{Cl}^{-}$ligand associated with the electron transfer [91].

\section{Photocatalytic oxidation of substrates}

Because $\left[\mathrm{Ru}^{\mathrm{III}}(\mathrm{bpy})_{3}\right]^{3+}$ can be produced by photoinduced electron transfer from the triplet excited state of $\left[\mathrm{Ru}^{\mathrm{II}}(\mathrm{bpy})_{3}\right]^{2+}\left(\left[\mathrm{Ru}(\mathrm{bpy})_{3}\right]^{2+*} ;{ }^{*}\right.$ denotes the excited state) to electron acceptors [94], substrates can be oxygenated by electron acceptors with $\mathrm{H}_{2} \mathrm{O}$ as an oxygen source using $\left[\mathrm{Ru}^{\mathrm{II}}(\mathrm{bpy})_{3}\right]^{2+}$ as a photocatalyst and $(\mathrm{P}) \mathrm{Mn}^{\mathrm{III}}$ as a substrate oxygenation catalyst [95]. Gray and co-workers indeed reported formation of iron(IV)-oxo porphyrin $\pi$-radical cations, the so-called Compound I (Cpd I), in photocatalytic oxidation of horseradish peroxidase (HRP) by $\left[\mathrm{Co}^{\mathrm{III}}\left(\mathrm{NH}_{3}\right)_{5} \mathrm{Cl}\right]^{2+}[96-98]$. Efficient oxygenation of water soluble substrates also occurred via photoinduced electron transfer from $\left[\mathrm{Ru}(\mathrm{bpy})_{3}\right]^{2+*}$ to $\left[\mathrm{Co}^{\mathrm{III}}\left(\mathrm{NH}_{3}\right)_{5} \mathrm{Cl}\right]^{2+}$ to afford $\left[\mathrm{Ru}^{\mathrm{III}}(\mathrm{bpy})_{3}\right]^{3+}$ as a stronger one-electron oxidant, the electron-transfer oxidation of $(\mathrm{P}) \mathrm{Mn}^{\mathrm{III}}$ by two equiv. of $\left[\mathrm{Ru}^{\mathrm{III}}(\mathrm{bpy})_{3}\right]^{3+}$ to produce $\left[(\mathrm{P}) \mathrm{Mn}^{\mathrm{V}}(\mathrm{O})\right]^{+}$, which oxygenates substrates as shown in Scheme 9, where $\mathrm{H}_{2} \mathrm{O}$ is used as an oxygen source [95]. Photoirradiation $(\lambda>430 \mathrm{~nm})$ of a phosphate buffer (pH 7.4) containing (TMPS)Mn ${ }^{\mathrm{III}}(\mathrm{OH}),\left[\mathrm{Ru}^{\mathrm{II}}(\mathrm{bpy})_{3}\right]^{2+}$, and $\left[\mathrm{Co}^{\mathrm{III}}\left(\mathrm{NH}_{3}\right)_{5} \mathrm{Cl}\right]^{2+}$ in the presence of sodium $p$-styrene sulfonate $(\mathrm{NaSS})$ and sodium 4-ethylbenzene sulfonate afforded the corresponding epoxide and alcohol products, respectively (Table 2) [95]. When $\left[\mathrm{Co}^{\mathrm{III}}\left(\mathrm{NH}_{3}\right)_{5} \mathrm{Cl}\right]^{2+}$ was replaced by other one-electron oxidants (e.g. hexaamineruthenium(III) trichloride $\left.\left(\left[\mathrm{Ru}^{\mathrm{III}}\left(\mathrm{NH}_{3}\right)_{6}\right]^{3+}\right)\right)$, however, no 


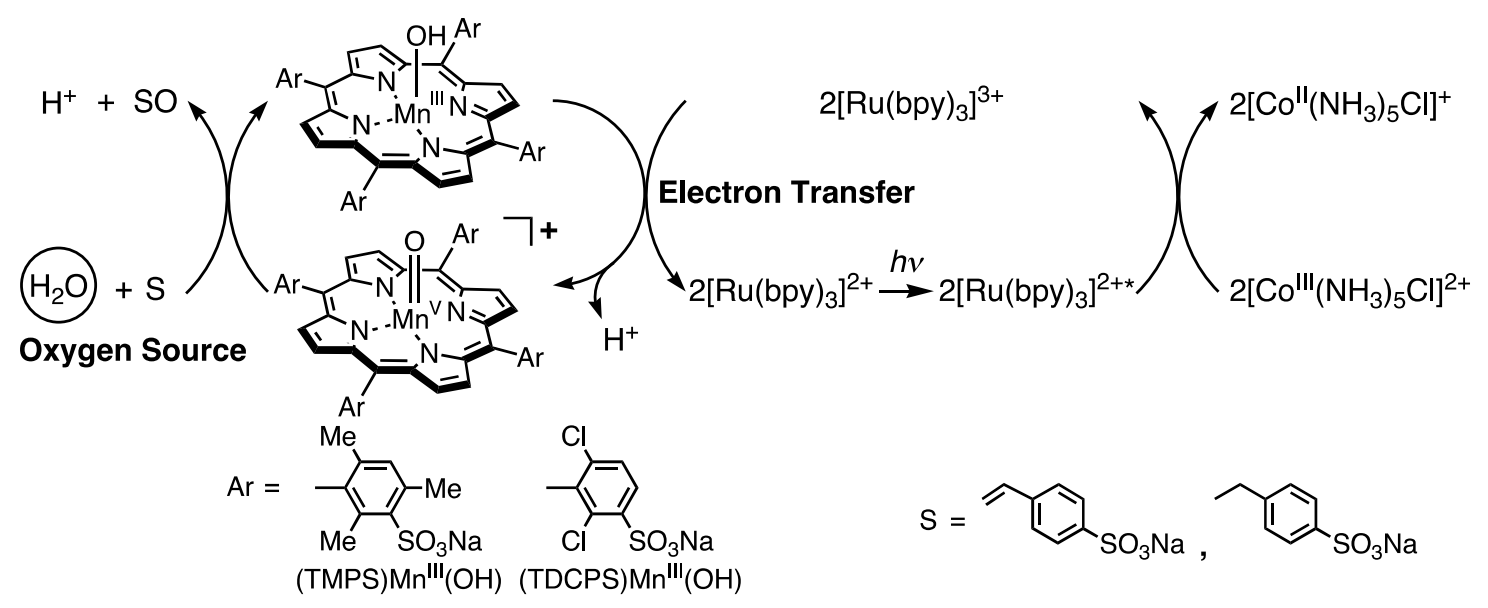

Scheme 9. Mechanism of the photocatalytic oxygenation of water soluble substrates (S) with $\left[(\mathrm{P}) \mathrm{Mn}^{\mathrm{V}}(\mathrm{O})\right]^{+}$produced by electron-transfer oxidation of $\left[(\mathrm{P}) \mathrm{Mn}^{\mathrm{III}}(\mathrm{OH})\right]$ with $\left[\mathrm{Ru}^{\mathrm{III}}(\mathrm{bpy})_{3}\right]^{3+}$ via photoinduced electron transfer from $\left[\mathrm{Ru}(\mathrm{bpy})_{3}\right]^{2+*}$ to $\left[\mathrm{Co}{ }^{\mathrm{III}}\left(\mathrm{NH}_{3}\right)_{5} \mathrm{Cl}\right]^{2+}$.

Table 2. Turnover numbers in photocatalytic oxygenation of sodium $p$-styrene sulfonate (NaSS) and sodium 4-ethylbenzene sulfonate in phosphate buffer ( $\mathrm{pH} 7.4)$ in $\mathrm{D}_{2} \mathrm{O}$ at 298 K. Reprinted with permission from Ref. [95]. Copyright 2011, Nature Publishing Group.

\begin{tabular}{|c|c|c|c|c|}
\hline catalyst & substrate & product & $\mathrm{TON}^{b}$ & Yields $(\%)^{c}$ \\
\hline (TMPS)Mn ${ }^{\mathrm{III}}(\mathrm{OH})$ & $\mathrm{NaSS}$ & epoxide & 450 & 90 \\
\hline (TDCPS) $\mathrm{Mn}^{\mathrm{III}}(\mathrm{OH})$ & $\mathrm{NaSS}$ & epoxide & 460 & 91 \\
\hline (TMPS)Mn ${ }^{\mathrm{III}}(\mathrm{OH})$ & sodium 4-ethylbenzene sulfonate & alchol & 60 & 11 \\
\hline (TDCPS)Mn ${ }^{\mathrm{III}}(\mathrm{OH})$ & sodium 4-ethylbenzene sulfonate & alchol & 70 & 13 \\
\hline
\end{tabular}

${ }^{a}$ Conditions : (porphyrin) $\mathrm{Mn}^{\mathrm{III}}(\mathrm{OH})\left(1.0 \times 10^{-5} \mathrm{M}\right),\left[\mathrm{Ru}(\mathrm{bpy})_{3}\right]^{2+}\left(1.0 \times 10^{-4} \mathrm{M}\right)$, substrate $\left(1.0 \times 10^{-2} \mathrm{M}\right),\left[\mathrm{Co}^{\mathrm{III}}\left(\mathrm{NH}_{3}\right)_{5} \mathrm{Cl}\right]^{2+}\left(1.0 \times 10^{-2} \mathrm{M}\right)$. Photoirradiation with Xe lamp through cut filter $(\lambda>430 \mathrm{~nm}) .15 \mathrm{~min}$.

${ }^{b}$ TON (turnover number) : (mol of product)/(mol of catalyst).

${ }^{c}$ Yields : (mol of product)/2(mol of $\left.\left[\mathrm{Co}^{\mathrm{III}}\left(\mathrm{NH}_{3}\right)_{5} \mathrm{Cl}\right]^{2+}\right)$.

photocatalytic epoxidation of $\mathrm{NaSS}$ occurred under otherwise the same experimental conditions because of fast back electron transfer from $\left[\mathrm{Ru}^{\mathrm{II}}\left(\mathrm{NH}_{3}\right)_{6}\right]^{2+}$ to $\left[\mathrm{Ru}^{\mathrm{III}}(\mathrm{bpy})_{3}\right]^{3+}[95]$. In the case of $\left[\mathrm{Co}^{\mathrm{III}}\left(\mathrm{NH}_{3}\right)_{5} \mathrm{Cl}\right]^{2+}$, such back electron transfer 
from $\left[\mathrm{Co}^{\mathrm{II}}\left(\mathrm{NH}_{3}\right)_{5} \mathrm{Cl}\right]^{+}$to $\left[\mathrm{Ru}^{\mathrm{III}}(\mathrm{bpy})_{3}\right]^{3+}$ was prevented due to fast irreversible decomposition of $\left[\mathrm{Co}^{\mathrm{II}}\left(\mathrm{NH}_{3}\right)_{5} \mathrm{Cl}\right]^{+}$upon the oxidation of $\left[\mathrm{Ru}^{\mathrm{II}}(\mathrm{bpy})_{3}\right]^{2+}$ to $\left[\mathrm{Ru}^{\mathrm{III}}(\mathrm{bpy})_{3}\right]^{3+}[95]$. Experiments using ${ }^{18} \mathrm{O}$-labeled water in the oxygenation of $\mathrm{NaSS}$ by $\left[\mathrm{Co}^{\mathrm{III}}\left(\mathrm{NH}_{3}\right)_{5} \mathrm{Cl}\right]^{2+}$ revealed that the percentage of ${ }^{18} \mathrm{O}$ found in the epoxide was nearly quantitative, indicating that the oxygen source in the oxygenation product was water as indicated in Scheme 9 [95]. The quantum efficiency of the photocatalytic oxygenation of $\mathrm{NaSS}(20 \mathrm{mM})$ by $\left[\mathrm{Co}^{\mathrm{III}}\left(\mathrm{NH}_{3}\right)_{5} \mathrm{Cl}\right]^{2+}(15 \mathrm{mM})$ was nearly $100 \%$ [95].

A nonheme iron(IV)-oxo complex $\left(\left[(\mathrm{N} 4 \mathrm{Py}) \mathrm{Fe}^{\mathrm{IV}}(\mathrm{O})\right]^{2+}\right)$ was generated in the photocatalytic oxidation of $\left[(\mathrm{N} 4 \mathrm{Py}) \mathrm{Fe}^{\mathrm{II}}\right]^{2+}$ by $\left[\mathrm{Co}^{\mathrm{III}}\left(\mathrm{NH}_{3}\right)_{5} \mathrm{Cl}\right]^{2+}$ via electron transfer from $\left[\mathrm{Ru}(\mathrm{bpy})_{3}\right]^{2+*}$ to $\left[\mathrm{Co}^{\mathrm{III}}\left(\mathrm{NH}_{3}\right)_{5} \mathrm{Cl}\right]^{2+}$ and stepwise electron-transfer oxidation of $\left[(\mathrm{N} 4 \mathrm{Py}) \mathrm{Fe}^{\mathrm{II}}\right]^{2+}$ with two equiv. of $\left[\mathrm{Ru}^{\mathrm{III}}(\mathrm{bpy})_{3}\right]^{3+}$ and $\mathrm{H}_{2} \mathrm{O}$ as an oxygen source (Scheme 10) [99]. $\left[(\mathrm{N} 4 \mathrm{Py}) \mathrm{Fe}^{\mathrm{IV}}(\mathrm{O})\right]^{2+}$ was synthesized independently by both the chemical oxidation of $\left[(\mathrm{N} 4 \mathrm{Py}) \mathrm{Fe}^{\mathrm{II}}\right]^{2+}$ with two equiv. of $\left[\mathrm{Ru}^{\mathrm{III}}(\mathrm{bpy})_{3}\right]^{3+}$ and electrochemical oxidation of $\left[(\mathrm{N} 4 \mathrm{Py}) \mathrm{Fe}^{\mathrm{II}}\right]^{2+}$ in the presence of $\mathrm{H}_{2} \mathrm{O}$ [99]. A nonheme iron(IV)-oxo complex was also generated in a $\mathrm{Ru}^{\mathrm{II}}-\mathrm{Fe}^{\mathrm{II}}$ supramolecular assembly via photoinduced electron transfer from the excited state of the $\mathrm{Ru}^{\mathrm{II}}$ moiety to $\left[\mathrm{Co}^{\mathrm{III}}\left(\mathrm{NH}_{3}\right)_{5} \mathrm{Cl}\right]^{2+}$ and the subsequent stepwise electron-transfer oxidation of the $\mathrm{Fe}^{\mathrm{II}}$ moiety [100].

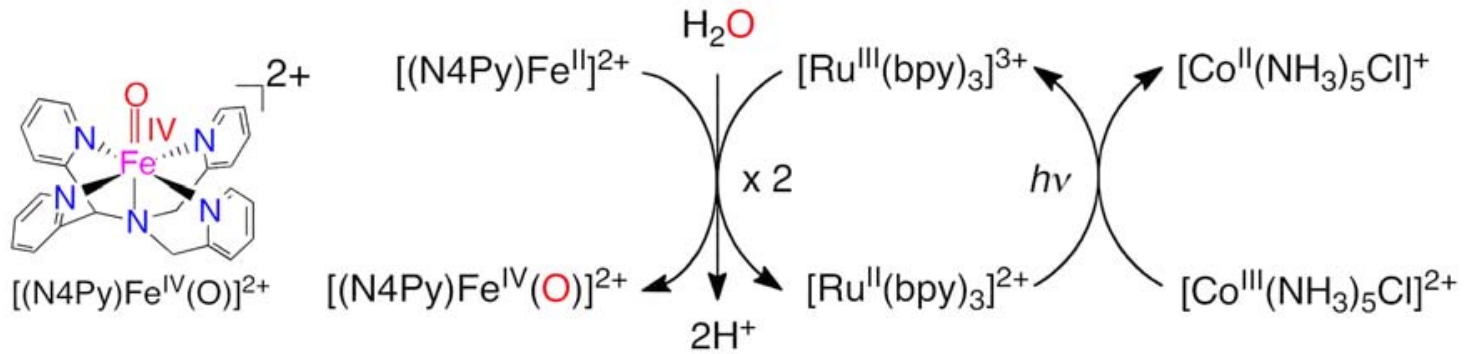

Scheme 10. Generation of a nonheme iron(IV)-oxo complex $\left(\left[(\mathrm{N} 4 \mathrm{Py}) \mathrm{Fe}^{\mathrm{IV}}(\mathrm{O})\right]^{2+}\right)$ with $\left[\mathrm{Ru}^{\mathrm{III}}(\mathrm{bpy})_{3}\right]_{3+}$ and $\mathrm{H}_{2} \mathrm{O}$ via photoinduced electron transfer from $\left[\mathrm{Ru}(\mathrm{bpy})_{3}\right]^{2+*}$ to $\left[\mathrm{Co}^{\mathrm{III}}\left(\mathrm{NH}_{3}\right)_{5} \mathrm{Cl}\right]^{2+}$. Reprinted with permission from Ref. [99]. Copyright 2011, American Chemical Society. 
A nonheme manganese $(\mathrm{IV})-$ oxo complex, $\left[(\mathrm{BQCN}) \mathrm{Mn}^{\mathrm{IV}}(\mathrm{O})\right]^{2+}(\mathrm{BQCN}=$ $N, N^{\prime}$-dimethyl- $N, N^{\prime}$-bis(8-quinolyl)cyclohexanediamine), was also generated in the photocatalytic oxidation of $\left[(\mathrm{BQCN}) \mathrm{Mn}^{\mathrm{II}}\right]^{2+}$ by $\left[\mathrm{Co}^{\mathrm{III}}\left(\mathrm{NH}_{3}\right)_{5} \mathrm{Cl}\right]^{2+}$ with water as an oxygen source (Scheme 11) [101,102]. The photocatalytic oxygenation of organic substrates such as alcohols and sulfides by $\left[\mathrm{Co}^{\mathrm{III}}\left(\mathrm{NH}_{3}\right)_{5} \mathrm{Cl}\right]^{2+}$ was made possible by using $\left[\mathrm{Ru}^{\mathrm{II}}(\mathrm{bpy})_{3}\right]^{2+}$ as a photocatalyst and $\left[(\mathrm{BQCN}) \mathrm{Mn}^{\mathrm{II}}\right]^{2+}$ as a substrate oxygenation catalyst in a mixture solvent of deaerated acetate buffer $(\mathrm{pH}$ 4.0) and $\mathrm{MeCN}(\mathrm{v} / \mathrm{v} 19: 1)$ [102]. The photocatalytic enantioselective oxygenation of thioanisole was also enabled by using $\left[\mathrm{Ru}^{\mathrm{II}}(\mathrm{bpy})_{3}\right]^{2+}$ as a photocatalyst and a bissulfonato $\mathrm{Mn}^{\mathrm{III}}$-corrole/Bovine Serum Albumin (BSA) artificial metalloenzyme via formation of manganese $(\mathrm{V})$-oxo species that performed oxygen atom transfer (OAT) to thioanisole [103].

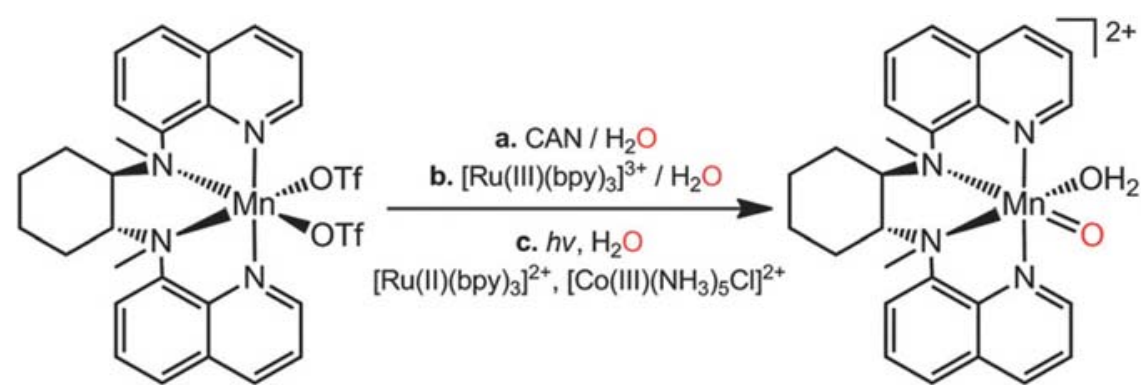

Scheme 11. Generation of a nonheme manganese(IV)-oxo complex $\left(\left[(\mathrm{BQCN}) \mathrm{Mn}^{\mathrm{IV}}(\mathrm{O})\right]^{2+}\right)$ by electron-transfer oxidation of $\left[(\mathrm{BQCN}) \mathrm{Mn}^{\mathrm{II}}\right]^{2+}$ with (a) $\mathrm{CAN}$, and (b) $\left[\mathrm{Ru}(\mathrm{bpy})_{3}\right]^{3+}$, and (c) via photoinduced electron transfer from $\left[\mathrm{Ru}(\mathrm{bpy})_{3}\right]^{2+*}$ to $\left[\mathrm{Co}^{\mathrm{III}}\left(\mathrm{NH}_{3}\right)_{5} \mathrm{Cl}\right]^{2+}$ with water as an oxygen source. Reprinted with permission from Ref. [102]. Copyright 2015, Royal Society of Chemistry.

Photocatalytic oxygenation of substrates by $\left[\mathrm{Co}^{\mathrm{III}}\left(\mathrm{NH}_{3}\right)_{5} \mathrm{Cl}\right]^{2+}$ also occurred using $\left[\mathrm{Ru}^{\mathrm{II}}(\mathrm{bpy})_{3}\right]^{2+}$ as a photocatalyst and $\mathrm{Ru}^{\mathrm{II}}$-pyridylamine complexes as substrate oxygenation catalysts in aqueous Britton-Robinson (B.-R.) buffer solutions ( $\mathrm{pH}$ 1.8) [104]. The product of the oxygenation of NaSS was only the corresponding benzaldehyde derivative, in contrast to the case in which oxidation of the same substrate with CAN as 
a sacrificial oxidant gave the corresponding arylaldehyde and benzoic acid derivative in the ratio of 68:32 [42]. The photocatalytic systems exhibited excellent performance as demonstrated by high turnover numbers (TONs; e.g., 8700) and high selectivity in oxidation reactions of alcohols and alkenes to afford the corresponding aldehydes or ketones [104].

Photocatalytic oxidation of organic compounds also proceeded efficiently in a hybrid system with ruthenium-aqua complexes as catalysts, $\mathrm{BiVO}_{4}$ as a photocatalyst, $\left[\mathrm{Co}^{\mathrm{III}}\left(\mathrm{NH}_{3}\right)_{5} \mathrm{Cl}\right]^{2+}$ as a sacrificial electron acceptor and water as an oxygen source [105]. Dinuclear and trinuclear $\mathrm{Ru}$ cluster photocatalysts that contain $\mathrm{Ru}(\mathrm{II})$ photosensitizers and a $\mathrm{Ru}(\mathrm{II})$ reaction center exhibited activity in the oxygenation of a sulfide and alkenes using $\left[\mathrm{Co}^{\mathrm{III}}\left(\mathrm{NH}_{3}\right)_{5} \mathrm{Cl}\right]^{2+}$ as a sacrificial electron acceptor and water as an oxygen source [106-109].

\section{Photocatalytic oxidation of water}

$\left[\mathrm{Ru}^{\mathrm{III}}(\mathrm{bpy})_{3}\right]^{3+}$ can also oxidize water in the presence of various water oxidation catalysts (WOCs) [Eq. (7)] [38,94,101,109-125]. The highest turnover frequency $\left(\mathrm{TOF}=(1.6-2.2) \times 10^{3} \mathrm{~s}^{-1}\right)$ was obtained using a tetranuclear cobalt polyoxometalate, $\mathrm{Na}_{10}\left[\mathrm{Co}_{4}\left(\mathrm{H}_{2} \mathrm{O}\right)_{2}\left(\mathrm{VW}_{9} \mathrm{O}_{34}\right)_{2}\right] \cdot 35 \mathrm{H}_{2} \mathrm{O}(\mathbf{1 1})$, as a WOC in a sodium borate buffer at $\mathrm{pH} 9.0$ [125]. Because $\left[\mathrm{Ru}^{\mathrm{III}}(\mathrm{bpy})_{3}\right]^{3+}$ can be produced by photoinduced electron transfer from $\left[\mathrm{Ru}(\mathrm{bpy})_{3}\right]^{2+*}$ to persulfate $\left(\mathrm{S}_{2} \mathrm{O}_{8}{ }^{2-}\right)$, water can be oxidized by persulfate to evolve $\mathrm{O}_{2}$ in the presence of WOC [Eq. (8)] [94]. The yield of $\mathrm{O}_{2}$ in the photocatalytic oxidation of water by persulfate with $\left[\mathrm{Ru}^{\mathrm{II}}(\mathrm{bpy})_{3}\right]^{2+}$ and $\mathbf{1 1}$ at $\mathrm{pH} 9.0$ was $75 \%$ [125].

$$
\begin{aligned}
& 4\left[\mathrm{Ru}^{\mathrm{III}}(\mathrm{bpy})_{3}\right]^{3+}+\underset{\text { WOC }}{2 \mathrm{H}_{2} \mathrm{O}} \underset{-----\rightarrow}{\rightarrow} 4\left[\mathrm{Ru}^{\mathrm{II}}(\mathrm{bpy})_{3}\right]^{2+}+\mathrm{O}_{2}+4 \mathrm{H}^{+} \\
& 2 \mathrm{~S}_{2} \mathrm{O}_{8}{ }^{2-}+\underset{\left[\mathrm{Ru}_{2} \mathrm{O}(\mathrm{bpy})_{3}\right]^{2+}, \mathbf{1 1}}{\mathrm{I1}} \mathrm{h}
\end{aligned}
$$


The mechanism of the photocatalytic water oxidation by persulfate was reported using a bis-hydroxo-bridged dinuclear $\mathrm{Co}^{\mathrm{III}}$-pyridylmethylamine complex, $\left[\mathrm{Co}_{2}(\mu\right.$ $\left.\mathrm{OH})_{2}(\mathrm{TPA})_{2}\right]\left(\mathrm{ClO}_{4}\right)_{4}(\mathbf{1 2})$, as a homogeneous WOC [126]. The crystal structure of 12 is shown in Fig. 12. Complex $\mathbf{1 2}$ acts as a homogeneous catalyst for the photocatalytic water oxidation by persulfate with $\left[\mathrm{Ru}^{\mathrm{II}}(\mathrm{bpy})_{3}\right]^{2+}$ as a photocatalyst to afford a high quantum yield $(44 \%)$ with a large turnover number $(\mathrm{TON}=742)$ without forming catalytically active Co-oxide nanoparticles [127-129]. The dinuclear complex 12 undergoes the electron-transfer oxidation to afford the putative bis- $\mu$-oxyl dinuclear $\mathrm{Co}^{\mathrm{III}}$ complex accompanied by removal of protons [126]. The isotope-labeling experiments using a mixture of $\mathrm{H}_{2}{ }^{16} \mathrm{O}$ and $\mathrm{H}_{2}{ }^{18} \mathrm{O}$ revealed that the $\mathrm{O}-\mathrm{O}$ bond formation occurred in the $\mathrm{Co}_{2}{ }_{2}\left(\mu-\mathrm{O}^{\circ-}\right)_{2}$ core in an

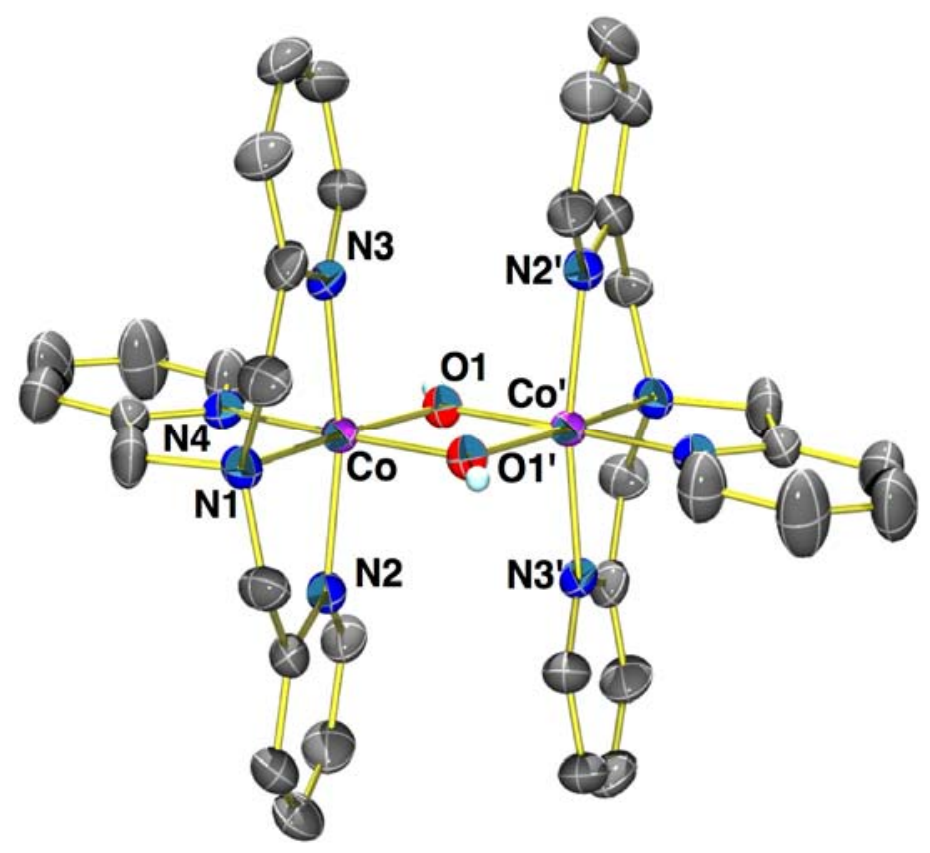

Fig. 12. An ORTEP drawing of the cation part of 12. All the thermal ellipsoids are drawn at the 50\% probability level. Reprinted with permission from Ref. [126]. Copyright 2016, American Chemical Society. 
intramolecular radical-coupling mechanism, affording a dinuclear $\mu$-peroxo-Co ${ }^{\text {III }}$ complex as an intermediate in the catalytic water oxidation (Scheme 12) [126].

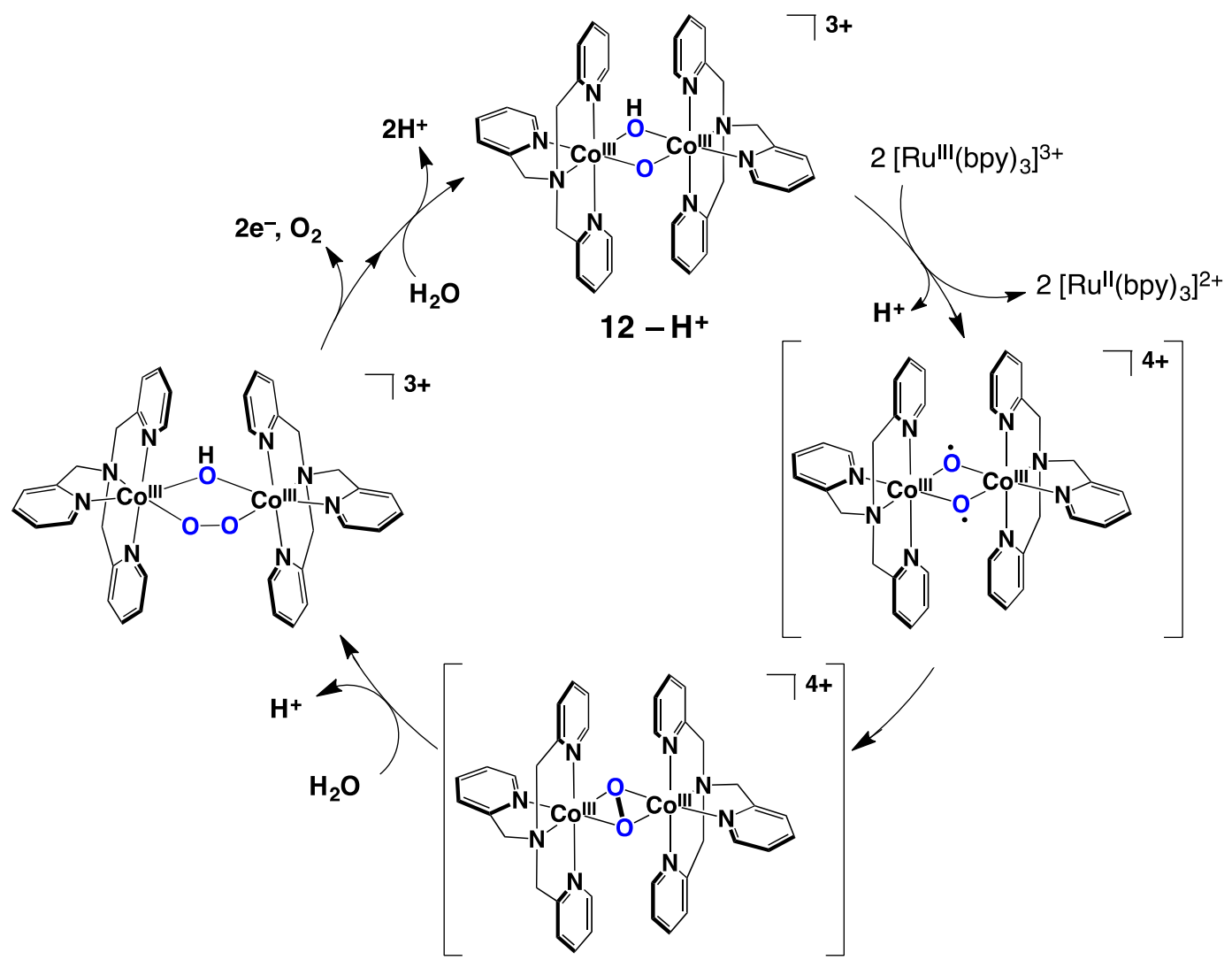

Scheme 12. Mechanism of the photocatalytic water oxidation with a bis-hydroxo-bridged dinuclear $\mathrm{Co}^{\mathrm{III}}$-pyridylmethylamine complex (12) via the electron-transfer oxidation of $12-\mathrm{H}^{+}$with $\left[\mathrm{Ru}(\mathrm{bpy})_{3}\right]^{3+}$ and the $\mathrm{O}-\mathrm{O}$ bond formation in the $\mathrm{Co}^{\mathrm{III}} 2\left(\mu-\mathrm{O}^{-}\right)_{2}$ core by an intramolecular radical-coupling to produce a dinuclear $\mu$-peroxo- $\mathrm{Co}^{\mathrm{III}}$ complex and the further oxidation with $\left[\mathrm{Ru}(\mathrm{bpy})_{3}\right]^{3+}$. Reprinted with permission from Ref. [126]. Copyright 2016, American Chemical Society.

\section{Concluding remarks}

High-valent metal-oxo complexes produced by successive electron-transfer oxidation of metal complexes with one-electron oxidants in the presence of water oxygenate various substrates, when metal complexes act as catalysts for oxygenation of substrates by one-electron oxidants with water as an oxygen source. 
The one-electron oxidants can be replaced by much weaker ones by combining photoinduced electron transfer from $\left[\mathrm{Ru}(\mathrm{bpy})_{3}\right]^{2+*}$ to the weaker oxidants such as $\left[\mathrm{CoCl}\left(\mathrm{NH}_{3}\right)_{5}\right]^{2+}$ and $\mathrm{S}_{2} \mathrm{O}_{8}{ }^{2-}$, which should undergo irreversible decomposition upon the electron-transfer reduction in competition with the back electron transfer. High-valent metal-oxo complexes can also act as reactive intermediates for the photocatalytic water oxidation as well as the thermal catalytic water oxidation by one-electron oxidants. The catalytic reactivity of metal complexes in oxygenation of substrates using water as an oxygen source including water oxidation has been controlled by the electronic and steric effects of ligands. The further elaborate design of ligands of metal complexes will lead to development of more efficient, selective and robust catalysts for thermal and photocatalytic oxidation of substrates including water oxidation.

\section{Acknowledgements}

The authors gratefully acknowledge the contributions of their collaborators and co-workers mentioned in the cited references, and financial supports from ALCA and SENTAN projects from JST and JSPS KAKENHI (Grant Numbers 16H02268 to S.F. and $15 \mathrm{H} 00915$ to T.K.) from MEXT, Japan, and from the NRF of Korea through the CRI (NRF-2012R1A3A2048842 to W.N.) and GRL (NRF-201000353 to W.N.).

\section{References}

[1] C. Krebs, D.G. Fujimori, C.T. Walsh, J.M. Bollinger, Jr., Acc. Chem. Res. 40 (2007) 484.

[2] J.T. Groves, J. Inorg. Biochem. 100 (2006) 434.

[3] B. Meunier, S.P. de Visser, S. Shaik, Chem. Rev. 104 (2004) 3947.

[4] H. Fujii, Coord. Chem. Rev. 226 (2002) 51.

[5] C. Jung, Biochim. Biophys. Acta 1814 (2011) 46. 
[6] C.E. Tinberg, S.J. Lippard, Acc. Chem. Res. 44 (2011) 280.

[7] A.D. Ryabov, Adv. Inorg. Chem. 65 (2013) 117.

[8] J. Hohenberger, K. Ray, K. Meyer, Nat. Commun. 3 (2012) 1718.

[9] A.S. Borovik, Chem. Soc. Rev. 40 (2011) 1870.

[10] W. Nam, Acc. Chem. Res. 40 (2007) 522.

[11] K.L. Stone, A.S. Borovik, Curr. Opin. Chem. Biol. 13 (2009) 114.

[12] W. Nam, Acc. Chem. Res. 48 (2015) 2415.

[13] W. Nam, Y.-M. Lee, S. Fukuzumi, Acc. Chem. Res. 47 (2014) 1146.

[14] S. Fukuzumi, K. Ohkubo, Y.-M. Lee, W. Nam, Chem.-Eur. J. 21 (2015) 17548.

[15] K. Ray, F.F. Pfaff, B. Wang, W. Nam, J. Am. Chem. Soc. 136 (2014) 13942.

[16] M. Costas, M.P. Mehn, M.P. Jensen, L. Que, Jr., Chem. Rev. 104 (2004) 939.

[17] W.N. Oloo, L. Que, Jr., Acc. Chem. Res. 48 (2015) 2612.

[18] M. Puri, L. Que, Jr., Acc. Chem. Res. 48 (2015) 2443.

[19] N. Gagnon, W.B. Tolman, Acc. Chem. Res. 48 (2015) 2126.

[20] L.G. Denisov, T.M. Makris, S.G. Sligar, L. Schlichting, Chem. Rev. 105 (2005) 2253.

[21] P.R. Ortiz de Montellano, Chem. Rev. 110 (2010) 932.

[22] T.H. Yosca, J. Rittle, C.M. Krest, E.L. Onderko, A. Silakov, J.C. Calixto, R.K. Behan, M.T. Green, Science 342 (2013) 825.

[23] C.M. Krest, E.L. Onderko, T.H. Yosca, J.C. Calixto, R.F. Karp, J. Livada, J. Rittle, M.T. Green, J. Biol. Chem. 288 (2013) 17074.

[24] J.T. Groves, Nat. Chem. 6 (2014) 89.

[25] F.P. Guengerich, J. Biol. Chem. 288 (2013) 17063.

[26] O. Shoji, Y. Watanabe, J. Biol. Inorg. Chem. 19 (2014) 529.

[27] U. Pérez, H.B. Dunford, Biochim. Biophys. Acta 1038 (1990) 98.

[28] S.P. de Visser, S. Shaik, P.K. Sharma, D. Kumar, W. Thiel, J. Am. Chem. Soc. 125 (2003) 15779.

[29] J.P. McEvoy, G.W. Brudvig, Chem. Rev. 106 (2006) 4455.

[30] M.M. Najafpour, G. Renger, M. Holynska, A.N. Moghaddam, E.-M. Aro, R. Carpentier, H. Nishihara, J.J. Eaton-Rye, J.-R. Shen, S.I. Allakhverdiev, Chem. Rev. 116 (2016) 288.

[31] J.D. Blakemore, R.H. Crabtree, G.W. Brudvig, Chem. Rev. 115 (2015) 12974.

[32] J.-R. Shen, Ann. Rev. Plant Biol. 66 (2015) 23. 
[33] B.A. Moyer, T.J. Meyer, J. Am. Chem. Soc. 100 (1978) 3601.

[34] C.-M. Che, W.-T. Tang, W.-T. Wong, T.-F. Lait, J. Am. Chem. Soc. 111 (1989) 9048.

[35] D.L. Ashford, M.K. Gish, A.K. Vannucci, M.K. Brennaman, J.L. Templeton, J.M. Papanikolas, T.J. Meyer, Chem. Rev. 115 (2015) 13006.

[36] X. Sala, S. Maji, R. Bofill, J. García-Antón, L. Escriche, A. Llobet, Acc. Chem. Res. 47 (2014) 504.

[37] Q. Zenga, F.W. Lewis, L.M. Harwood, F. Hartl, Coord. Chem. Rev. 304-305 (2015) 88 .

[38] M. Okamura, S. Masaoka, Chem.-Asian J. 10 (2015) 306.

[39] S. Fukuzumi, Coord. Chem. Rev. 257 (2013) 1564.

[40] T. Ishizuka, S. Ohzu, T. Kojima, Synlett 25 (2014) 1667.

[41] S. Fukuzumi, Dalton Trans. 44 (2015) 6696.

[42] Y. Hirai, T. Kojima, Y. Mizutani, Y. Shiota, K. Yoshizawa, S. Fukuzumi, Angew. Chem., Int. Ed. 47 (2008) 5772.

[43] I.R. Paeng, K. Nakamoto, J. Am. Chem. Soc. 112 (1990) 3289.

[44] C.-M. Che, T.-F. Lai, K.-Y. Wong, Inorg. Chem. 26 (1987) 2289.

[45] D.F. Evans, D.A. Jakubovic, J. Chem. Soc., Dalton Trans. (1988) 2927.

[46] K. Sato, M. Aoki, R. Noyori, Science 281 (1998) 1646.

[47] T. Kojima, K. Nakayama, K. Ikemura, T. Ogura, S. Fukuzumi, J. Am. Chem. Soc. $133(2011) 11692$.

[48] S.N. Dhuri, K.-B. Cho, Y.-M. Lee, S.Y. Shin, J.H. Kim, D. Mandal, S. Shaik, W. Nam, J. Am. Chem. Soc. 137 (2015) 8623.

[49] W.-C. Cheng, W.-Y. Yu, J. Zhu, K.-K. Cheung, S.-M. Peng, C.-K. Poon, C.-M. Che, Inorg. Chim. Acta 24 (1996) 105.

[50] T. Kojima, Y. Hirai, T. Ishizuka, Y. Shiota, K. Yoshizawa, K. Ikemura, T. Ogura, S. Fukuzumi, Angew. Chem., Int. Ed. 49 (2010) 8449.

[51] S. Ohzu, T. Ishizuka, Y. Hirai, H. Jiang, M. Sakaguchi, T. Ogura, S. Fukuzumi, T. Kojima, Chem. Sci. 3 (2012) 3421.

[52] D. Schröder, S. Shaik, Angew. Chem., Int. Ed. 50 (2011) 3850.

[53] T. Kojima, S. Fukuzumi, Angew. Chem., Int. Ed. 50 (2011) 3852.

[54] Y.-M. Lee, S.N. Dhuri, S.C. Sawant, J. Cho, M. Kubo, T. Ogura, S. Fukuzumi, W. Nam, Angew. Chem., Int. Ed., 48 (2009) 1803. 
[55] P. Barman, A.K. Vardhaman, B. Martin, S.J. Wçrner, C.V. Sastri, P. Comba, Angew. Chem., Int. Ed. 54 (2015) 2095.

[56] S.W. Gersten, G.J. Samuels, T.J. Meyer, J. Am. Chem. Soc. 104 (1982) 4029.

[57] J.A. Gilbert, D.S. Eggleston, W.R. Murphy, Jr., D.A. Geselowitz, S.W. Gersten, D.J. Hodgson, T.J. Meyer, J. Am. Chem. Soc. 107 (1985) 3855.

[58] J.J. Concepcion, J.W. Jurss, M.K. Brennaman, P.G. Hoertz, A.O.T. Patrocinio, I.N.Y. Murakami, J.L. Templeton, T.J. Meyer, Acc. Chem. Res. 42 (2009) 1954.

[59] R. Cao, W. Lai, P. Du, Energy Environ. Sci. 5 (2012) 8134.

[60] D.G.H. Hetterscheid, J.N.H. Reek, Angew. Chem., Int. Ed. 51 (2012) 9740.

[61] D.J. Wasylenko, R.D. Palmer, C.P. Berlinguette, Chem. Commun. 49 (2013) 218.

[62] S. Berardi, S. Drouet, L. Francàs, C. Gimbert-Suriñach, M. Guttentag, C. Richmond, T. Stolla, A. Llobet, Chem. Soc. Rev. 43 (2014) 7501.

[63] A. Sartorel, M. Carraro, G. Scorrano, R.D. Zorzi, S. Geremia, N.D. McDaniel, S. Bernhard, M. Bonchio, J. Am. Chem. Soc. 130 (2008) 5006.

[64] Y.V. Geletii, B. Botar, P. Kögerler, D.A. Hillesheim, D.G. Musaev, C.L. Hill, Angew. Chem., Int. Ed. 47 (2008) 3896.

[65] Q. Yin, J.M. Tan, C. Besson, Y.V. Geletii, D.G. Musaev, A.E. Kuznetsov, Z. Luo, K.I. Hardcastle, C.L. Hill, Science 328 (2010) 342.

[66] M. Sadakane, M. Higashijima, Dalton Trans. (2003) 659.

[67] M. Sadakane, D. Tsukuma, M.H. Dickman, B. Bassil, U. Kortz, M. Higashijima, W. Ueda, Dalton Trans. (2006) 4271.

[68] M. Murakami, D. Hong, T. Suenobu, S. Yamaguchi, T. Ogura, S. Fukuzumi, J. Am. Chem. Soc. 133 (2011) 11605.

[69] D.J. Wasylenko, C. Ganesamoorthy, M.A. Henderson, B.D. Koivisto, H.D. Osthoff, C.P. Berlinguette, J. Am. Chem. Soc. 132 (2010) 16094.

[70] W.C. Ellis, N.D. McDaniel, S. Bernhard, T.J. Collins, J. Am. Chem. Soc. 132 (2010) 10990.

[71] J.L. Fillol, Z. Codolà, I. Garcia-Bosch, L. Gómez, J.J. Pla, M. Costas, Nat. Chem. 3 (2011) 807.

[72] G. Chen, L. Chen, S.-M. Ng, W.-L. Man, T.-C. Lau, Angew. Chem., Int. Ed. 52 (2013) 1789.

[73] D. Hong, S. Mandal, Y. Yamada, Y.-M. Lee, W. Nam, A. Llobet, S. Fukuzumi, Inorg. Chem. 52 (2013) 9522. 
[74] Z. Codolà, L. Gómez, S.T. Kleespies, L. Que, Jr., M. Costas, J. Lloret-Fillol, Nat. Commun. 6 (2015) 5865.

[75] S. Fukuzumi, Y. Morimoto, H. Kotani, P. Naumov, Y.-M. Lee, W. Nam, Nat. Chem. 2 (2010) 756.

[76] H. Yoon, Y.-M. Lee, X. Wu, K.-B. Cho, R. Sarangi, W. Nam, S. Fukuzumi, J. Am. Chem. Soc. 135 (2013) 9186.

[77] Y. Morimoto, H. Kotani, J. Park, Y.-M. Lee, W. Nam, S. Fukuzumi, J. Am. Chem. Soc. 133 (2011) 403.

[78] J. Park, Y. Morimoto, Y.-M. Lee, W. Nam, S. Fukuzumi, J. Am. Chem. Soc. 133 (2011) 5236.

[79] J. Park, Y. Morimoto, Y.-M. Lee, Y. You, W. Nam, S. Fukuzumi, Inorg. Chem. 50 (2011) 11612.

[80] J. Park, Y.-M. Lee, K. Ohkubo, W. Nam, S. Fukuzumi, Inorg. Chem. 54 (2015) 5806.

[81] J. Park, Y. Morimoto, Y.-M. Lee, W. Nam, S. Fukuzumi, Inorg. Chem. 53 (2014) 3618.

[82] J. Chen, Y.-M. Lee, K.M. Davis, X. Wu, M.S. Seo, K.-B. Cho, H. Yoon, Y.J. Park, S. Fukuzumi, Y.N. Pushkar, W. Nam, J. Am. Chem. Soc. 135 (2013) 6388.

[83] Y. Morimoto, J. Park, T. Suenobu, Y.-M. Lee, W. Nam, S. Fukuzumi, Inorg. Chem. $51(2012) 10025$.

[84] S. Fukuzumi, K. Ohkubo, Y. Morimoto, Phys. Chem. Chem. Phys. 14 (2012) 8472.

[85] P. Leeladee, R.A. Baglia, K.A. Prokop, R. Latifi, S.P. de Visser, D.P. Goldberg, J. Am. Chem. Soc. 134 (2012) 10397.

[86] Y.J. Park, J.W. Ziller, A.S. Borovik, J. Am. Chem. Soc. 133 (2011) 9258.

[87] C. Choe, L. Yang, Z. Lv, W. Mo, Z. Chen, G. Li, G. Yin, Dalton Trans. 44 (2015) 9182.

[88] Z. Chen, L. Yang, C. Choe, Z. Lv, G. Yin, Chem. Commun. 51 (2015) 1874.

[89] L. Dong, Y. Wang, Y. Lv, Z. Chen, F. Mei, H. Xiong, G. Yin, Inorg. Chem. 52 (2013) 5418.

[90] S. Bang, Y.-M. Lee, S. Hong, K.-B. Cho, Y. Nishida, M.S. Seo, R. Sarangi, S. Fukuzumi, W. Nam, Nat. Chem. 6 (2014) 934.

[91] S. Fukuzumi, T. Mizuno, T. Ojiri, Chem.-Eur. J. 18 (2012) 15794.

[92] R.A. Marcus, Ann. Rev. Phys. Chem. 15 (1964) 155. 
[93] R.A. Marcus, Angew. Chem., Int. Ed. Engl. 32 (1993) 1111.

[94] S. Fukuzumi, J. Jung, Y. Yamada, T. Kojima, W. Nam, Chem.-Asian J. 11 (2016) 1138.

[95] S. Fukuzumi, T. Kishi, H. Kotani, Y.-M. Lee, W. Nam, Nat. Chem. 3 (2011) 38.

[96] D.W. Low, J.R. Winkler, H.B. Gray, J. Am. Chem. Soc. 118 (1996) 117.

[97] J. Berglund, T. Pascher, J.R. Winkler, H.B. Gray, J. Am. Chem. Soc. 119 (1997) 2464.

[98] M.E. Ener, Y.-T. Lee, J.R. Winkler, H.B. Gray, L. Cheruzel, Proc. Natl. Acad. Sci. U.S.A. 107 (2010) 18783.

[99] H. Kotani, T. Suenobu, Y.-M. Lee, W. Nam, S. Fukuzumi, J. Am. Chem. Soc. 133 (2011) 3249.

[100] C. Herrero, A. Quaranta, M. Sircoglou, K. Sénéchal-David, A. Baron, I.M. Marín, C. Buron, J.-P. Baltaze, W. Leibl, A. Aukauloom, F. Bans, Chem. Sci. 6 (2015) 2323.

[101] S.C. Sawant, X. Wu, J. Cho, K.-B. Cho, S.H. Kim, M.S. Seo, Y.-M. Lee, M. Kubo, T. Ogura, S. Shaik, W. Nam, Angew. Chem., Int. Ed. 49 (2010) 8190.

[102] X. Wu, X. Yang, Y.-M. Lee, W. Nam, L. Sun, Chem. Commun. 51 (2015) 4013.

[103] C. Herrero, A. Quaranta, R. Ricoux, A. Trehoux, A. Mahammed, Z. Gross, F. Banse, J.-P. Mahy, Dalton Trans. 45 (2016) 706.

[104] S. Ohzu, T. Ishizuka, Y. Hirai, S. Fukuzumi, T. Kojima, Chem.-Eur. J. 19 (2013) 1563.

[105] X. Zhou, F. Li, X. Li, H. Li, Y. Wang, L. Sun, Dalton Trans. 44 (2015) 475.

[106] P. Guillo, O. Hamelin, P. Batat, G. Jonusauskas, N.D. McClenaghan, S. Ménage, Inorg. Chem. 51 (2012) 2222.

[107] T.-T. Li, F.-M. Li, W.-L. Zhao, Y.-H. Tian, Y. Chen, R. Cai, W.-F. Fu, Inorg. Chem. $54(2015) 183$.

[108] S. Phungsripheng, K. Kozawa, M. Akita, A. Inagaki, Inorg. Chem. 55 (2016) 3750.

[109] L.-Z. Zeng, C.-J. Wang, T.-T. Li, X. Gan, C. Li, W.-F. Fu, Catal. Commun. 68 (2015) 84.

[110] Y.V. Geletii, C. Besson, Y. Hou, Q. Yin, D.G. Musaev, D, Quiñonero, R. Cao, K.I. Hardcastle, A. Proust, P. Kögerler, C.L. Hill, J. Am. Chem. Soc. 131 (2009) 17360.

[111] Y.V. Geletii, Z. Huang, Y. Hou, D.G. Musaev, T. Lian, C.L. Hill, J. Am. Chem. Soc. $131(2009) 7522$. 
[112] C. Besson, Z. Huang, Y.V. Geletii, S. Lense, K.I. Hardcastle, D.G. Musaev, T. Lian, A. Proust, C.L. Hill, Chem. Commun. 46 (2010) 2784.

[113] M. Orlandi, R. Argazzi, A. Sartorel, M. Carraro, G. Scorrano, M. Bonchio, F. Scandola, Chem. Commun. 46 (2010) 3152.

[114] F. Puntoriero, G. La Ganga, A. Sartorel, M. Carraro, G. Scorrano, M. Bonchio, S. Campagna, Chem. Commun. 46 (2010) 4725.

[115] S. Roeser, F. Bozoglian, C.J. Richmond, A.B. League, M.Z. Ertem, L. Francàs, P. Miró, J. Benet-Buchholz, C.J. Cramer, A. Llobet, Catal. Sci. Technol. 6 (2016) 5088.

[116] W. Rabten, T. Åkermark, M.D. Kärkäs, H. Chen, J. Sun, P.G. Andersson, B. Åkermark, Dalton Trans. 45 (2016) 3272.

[117] J.W. Vickers, H. Lv, J.M. Sumliner, G. Zhu, Z. Luo, D.G. Musaev, Y.V. Geletii, C.L. Hill, J. Am. Chem. Soc. 135 (2013) 14110.

[118] Z. Huang, Z. Luo, Y.V. Geletii, J.W. Vickers, Q. Yin, D. Wu, Y. Hou, Y. Ding, J. Song, D.G. Musaev, C.L. Hill, T. Lian, J. Am. Chem. Soc. 133 (2011) 2068.

[119] G. Zhu, Y.V. Geletii, P. Kögerler, H. Schilder, J. Song, S. Lense, C. Zhao, K.I. Hardcastle, D.G. Musaevc, C.L. Hill, Dalton Trans. 41 (2012) 2084.

[120] H.-Y. Wang, E. Mijangos, S. Ott, A. Thapper, Angew. Chem., Int. Ed. 53 (2014) 14499.

[121] S. Tanaka, M. Annaka, K. Sakai, Chem. Commun. 48 (2012) 1653.

[122] T. Nakazono, A.R. Parent, K. Sakai, Chem.-Eur. J. 21 (2015) 6723.

[123] A.R. Parent, K. Sakai, ChemSusChem 7 (2014) 2070.

[124] B. Das, A. Orthaber, S. Ott, A. Thapper, Chem. Commun. 51 (2015) 13074.

[125] H. Lv, J. Song, Y.V. Geletii, J.W. Vickers, J.M. Sumliner, D.G. Musaev, P. Kögerler, P.F. Zhuk, J. Bacsa, G. Zhu, C.L. Hill, J. Am. Chem. Soc. 136 (2014) 9268.

[126] T. Ishizuka, A. Watanabe, H. Kotani, D. Hong, K. Satonaka, T. Wada, Y. Shiota, K. Yoshizawa, K. Ohara, K. Yamaguchi, S. Kato, S. Fukuzumi, T. Kojima, Inorg. Chem. 55 (2016) 1154.

[127] D. Hong, J. Jung, J. Park, Y. Yamada, T. Suenobu, Y.-M. Lee, W. Nam, S. Fukuzumi, Energy Environ. Sci. 5 (2012) 7606.

[128] S. Fukuzumi, D. Hong, Eur. J. Inorg. Chem. (2014) 645.

[129] S. Fukuzumi, D. Hong, Y. Yamada, J. Phys. Chem. Lett. 4 (2013) 3458. 